*ak RMIS View/Frint Document Cover Sheet tow

This document was retrieved from the Documentation and Records Manaqement (DRM) ISEARCH System. It is intended for Information only and may not be the most recent or updated version. Contact a Document Service Center (see Hanford Info for locations) if you need additional retrieval information.

Accession \#: D196023643

Document \#: SD-WM-ATR-108

Title/Desc:

NITROGEN TRAILER ACCEPTANCE TEST REPORT

Pages: 49 


\begin{tabular}{|c|c|}
\hline $\begin{array}{l}\text { 2. To: (Receiving Organization) } \\
\text { Characterization Plant } \\
\text { Engineering }\end{array}$ & $\begin{array}{l}\text { 3. From: (Originating Organization) } \\
\text { Characterization Equipment } \\
\text { Improvement }\end{array}$ \\
\hline $\begin{array}{l}\text { 5. Proj./Prog./Dept./Div.: } \\
\text { Core Sampling Aux. Equipment }\end{array}$ & $\begin{array}{l}\text { 6. Cog. Engr.: } \\
\text { J.L. Smalley }\end{array}$ \\
\hline $\begin{array}{l}\text { 8. Originator Remarks: } \\
\text { ETN-94-0023-F } \\
\text { This Acceptance Test Report i } \\
\text { The ATR documents compliance } \\
\text { Rev.1. }\end{array}$ & $\begin{array}{l}\text { transmitted for approval. } \\
\text { th specification WHC-S-0249 }\end{array}$ \\
\hline
\end{tabular}

11. Receiver Remarks:
4. Related EDT No.:

$N / A$

7. Purchase Order No.:

404870

9. Equip./Component No.:

$N / A$

10. System/Bldg./Facility:

200 General

12. Major Assm. Dwg. No.: N/A

13. Permit/Permit Application No.: $N / A$

14. Required Response Date: $5 / 12 / 95$

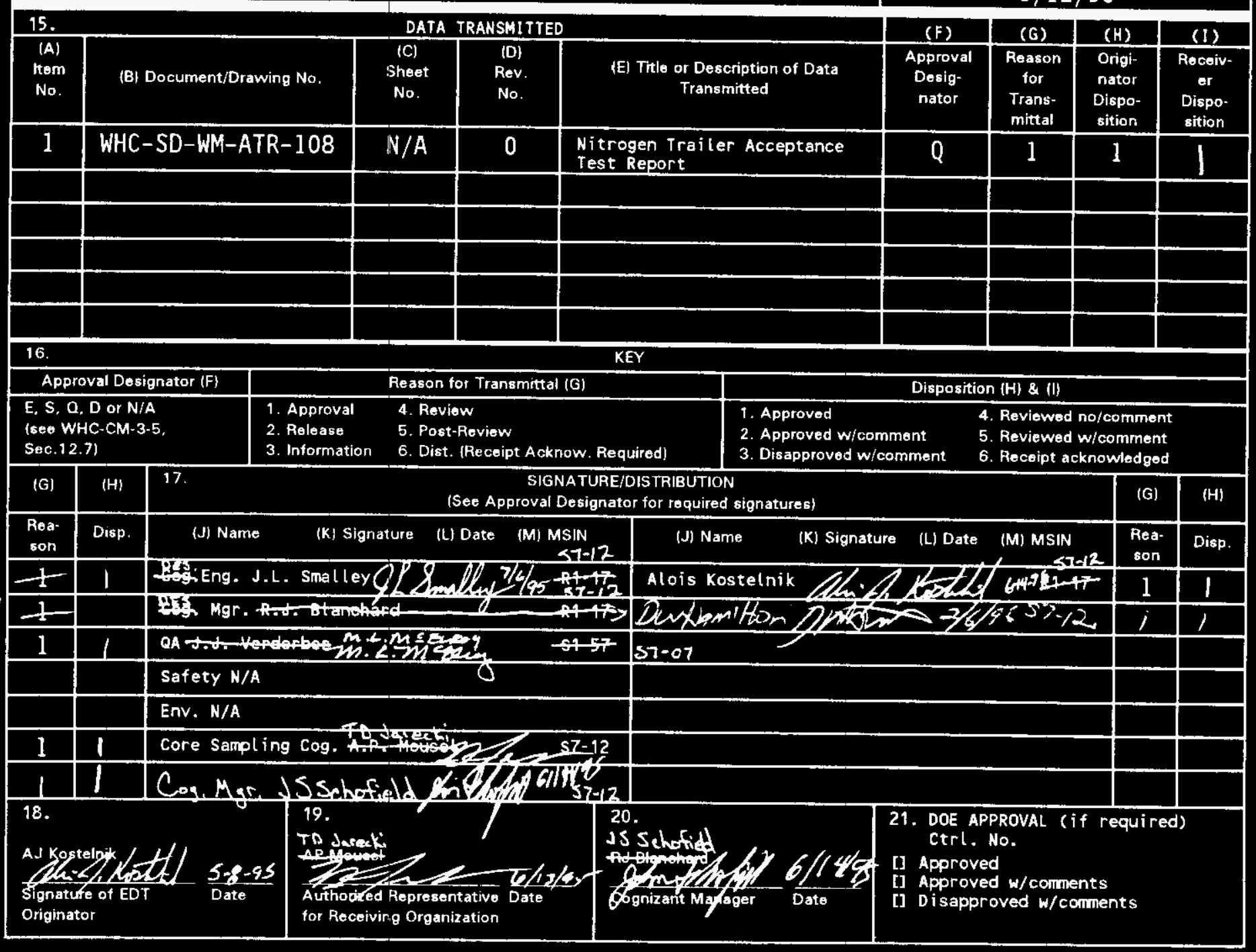

BD-7400-172-2 (04/94) GEF097 


\section{NITROGEN TRAILER ACCEPTANCE TEST REPORT}

ALOIS J. KOSTELNIK

WESTINGHOUSE HANFORD COMPANY, Richland, WA 99352

U.S. Department of Energy Contract DE-AC06-87RL10930
EDT/ECN: 612071
UC: 2070
Org Code: 75230
Charge Code: N4H2B
B\&R Code: $E$ U'3,20071
Total Pages: 47

Key Words: ETN-94-0023-F, Core Sampling, Liquid Nitrogen, Specification WHC-S-0249, Nitrogen Trailer, Cryogenic Experts, Norco, MVE, Minnesota Valley Engineering, Purchase Order 404870, Core Sampling Ancillary Equipment

Abstract: This Acceptance Test Report documents compliance with the requirements of specification WHC-S-0249. The equipment was tested according to WHC-SD-WM-ATP-108 Rev.0.

TRADEMARK DISCLAIMER. Reference herein to any specific commercial product, process, or service by trade name, tradenark, manufacturer, or otherwise, does not necessarily constitute or imply its endorsement, recommendation, or favoring by the United States Government or any agency thereof or its contractors or subcontractors.

Printed in the United States of America. To obtain copies of this document, contact: HHC/8CS Document Control Services, P.0. Box 1970, Mailstop H6-08, Richland WA 99352, Phone (509) 372-2420. Fax (509) 376-4989.
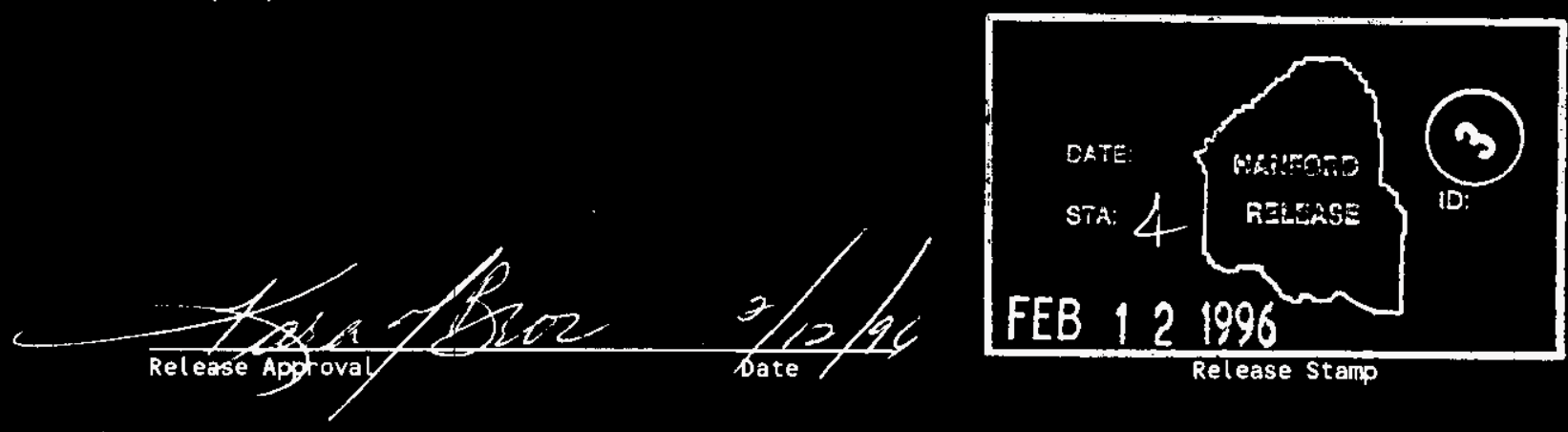

\section{Approved for Public Release}


WHC-SD-WM-ATR-108

REV.0

Page 2

\section{TABLE OF CONTENTS}

SUMMARY

Page 3

APPENDIX A (ATP results for Trailer VIN 1G9FS2724RA065101)

Page Al

APPENDIX B (ATP results for Trailer VIN 1G9FS2726RA065102)

Page B1

APPENDIX C (Receipt Inspection Report)

Page C1 


\section{SUMMARY}

The test was performed at Norco's facility in Boise, ID. All steps were completed at the time of testing. The exceptions could not be resolved while WHC personnel were present. The documentation required to close the exceptions was later provided by Norco.

The attached Appendix A contains the Acceptance Test Results for Trailer VIN 1G9FS2724RA065101. Appendix B contains the Acceptance Test Results for Trailer VIN 1G9FS2726RA065102. Appendix C includes the Receipt Inspection Report for both trailers. 


\section{RELEASE AUTHORIZATION}

Document Number: WHC-SD-WM-ATP-108, REV 0

Document Title: Acceptance Test Procedure for a Portable, SelfContained Nitrogen Supply

Release Date: $\quad$ October 4,1994

This document was reviewed following the procedures described in WHC-CM-3-4 and is:

APPROVED FOR PUBLIC RELEASE

WHC Information Release Administration Specialist:

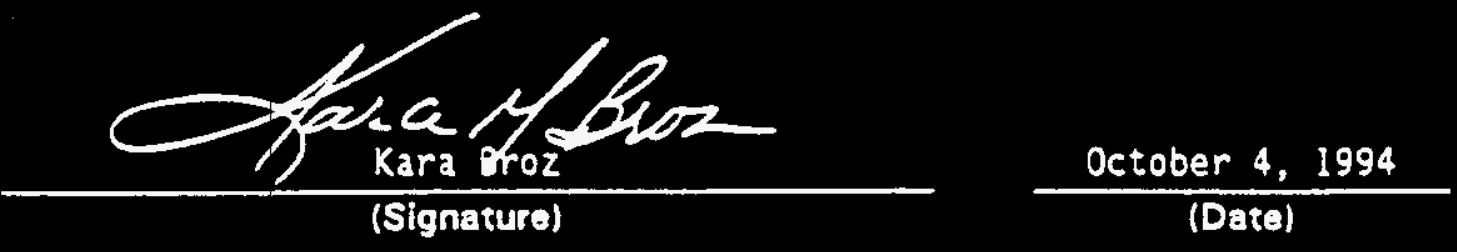


\begin{tabular}{|l|l|}
\hline $\begin{array}{l}\text { 2. To: (Receiving organization) } \\
\text { Core Sampling }\end{array}$ & $\begin{array}{l}\text { 3. From: corigimsing organization } \\
\text { Characterization Equipment }\end{array}$ \\
\hline 5. Proj./Prog./Dept./0iv.: & 6. Cog. Engr.: \\
Core Sampling Aux. Equipment & 3.L. Smalley \\
\hline
\end{tabular}

8. Originator Remarks:

ETN-94-0023-F

This Acceptance Test Procedure is transmitted for approval. A portion of the procedure was prepared by the Seller and will be performed at the Sellers location. The ATP will show compliance with specification WHC-S-0249 Rev.1.

\section{Receiver Remarks:}

6. Related Gor No.:

$$
N / A
$$

7. Purehase Order Na.: 404870

9. Equip./Component No.:

$$
N / A
$$

10. System/sldg./Foeflity:

\section{General}

12. Major Assm. Dws. No.:

$$
N / A
$$

13. Permit/Permit Apol ieation No.: $N / A$

16. Required Respense Dote: $10 / 4 / 94$

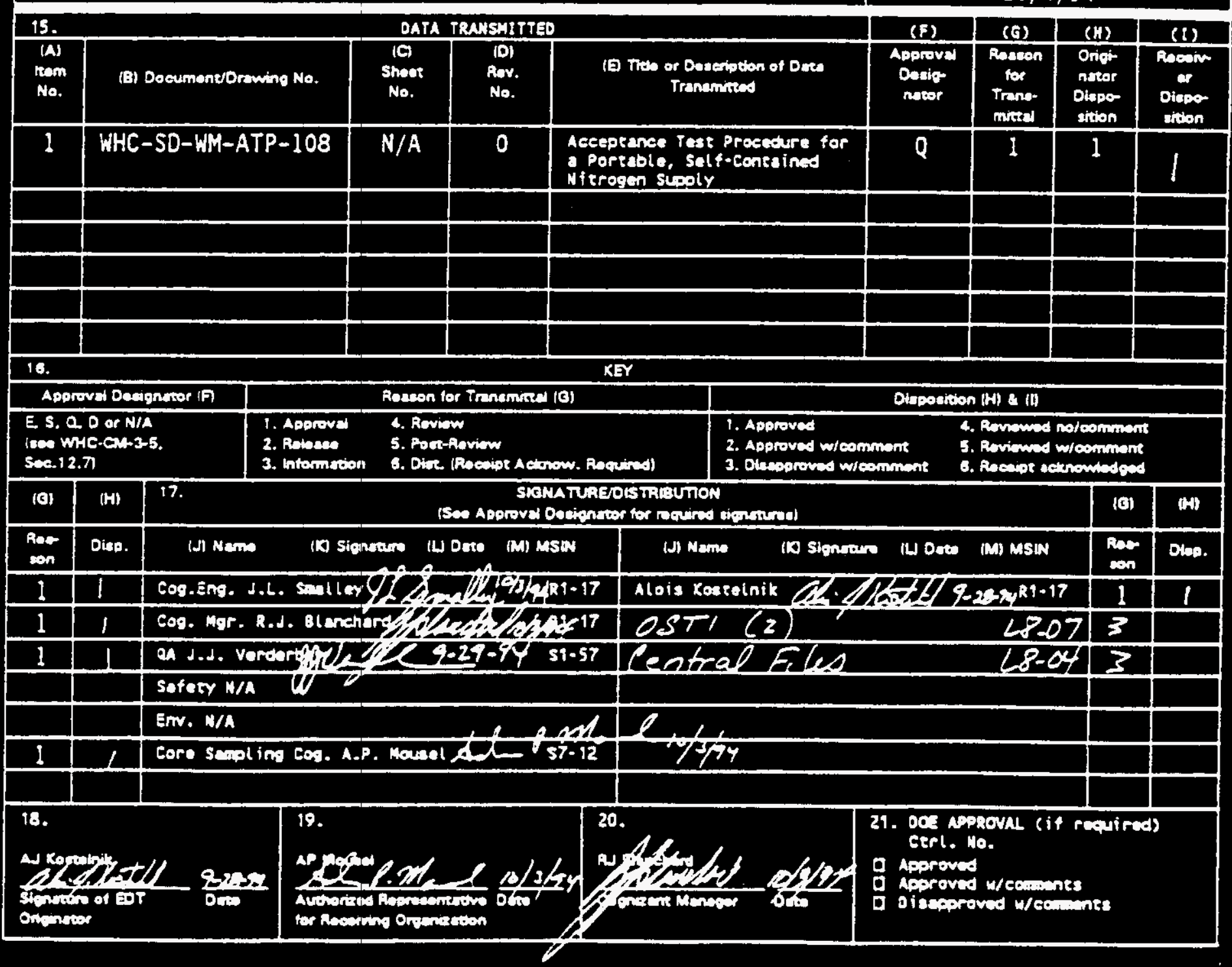


2. Tite

Acceptance Test Procedure for a Portable, SelfContained Nitrogen Supply

5. Key words

ETN-94-0023-F

Core Sampling, Nitrogen Trailer, Specification WHC-S-0249, Liquid Nitrogen, Norco, MVE, Minnesota Valley Engineering, Vaporizer, Cryogenic Experts Incorporated, CEXI, Purchase- Órder 404870, fore



WHC-SD-WLH-ATP-108 0

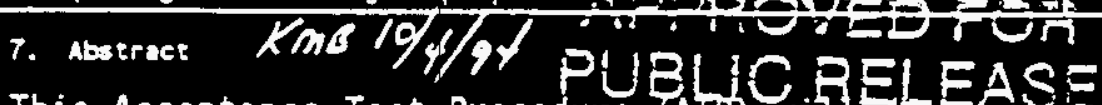

This Acceptance Test Procedure (ATP) wifl document compliance with the requirements of WHC-S-0249 Rev.l and ECN 606112. The equipment being tested is a Portable, SelfContained Nitrogen Supply. The unit was purchased as a Design and Fabrication procurement activity. The Functional Test was written by the Seller and is contained in Appendix. A. The Functional test will be performed by the Seller with representatives of the Hestinghouse Hanford Company performing inspection and witnessing the functional test at the Seller's location.

8. Pummese aNo USE of documeNT - This document was prepared son the with in the U.S. Departinerte of Energy and its eantractors Tt is to be wad anke to perform, di rect, or integen work undar U.S. Department of Energy eentracts. This doesunte is not approved for public release mindeviewed.

10.

RELEASE STAMP

Patent status - This decubent $-x$ since it is eransmited in advance of patent elearance is made orvilable in conf idence solely for use in performant of work undenenteces with the U.S. Departwene of in ry. This document is not bubs published nor its contents ombruise disseminated or wed for purposene ocher then specifigd bove before patent approval for sueh pelease of wre has begn weured, upon reques:, from the Patent Counsel, U.S. Departune Enargy fietd office, $R$ iehtand, th.

Disclatmer - This report was prepared as an account of work sponsered by an agency of the Uni ted States Govermant. Hei ther the United states Goverrmant nor any agency thereof, nar any of their elployees, nor any of their contractors, subsentrectors or their mployees, makes any warranty, expreas or illolfied, or assumes any teat liability or reaporsibility for the seeurecy, eampleteneas, or ony third party's we or the reaults of such we of uny informt ion, apparatus, product, or precess diselosed, or represtents thos its use would not infringe privotely and rights. Reforence harain to any spectific comereiol procuct, process, or service by treds nem, tracenark, manufacturer, or otherwise, does not neseatarily cenatitute or imply its andarscetant, recoumdation, or fovoring by the United states Government or any agency thereof of its centractors or subeentractors. The vicus and apiniens of authors expressed herein do not recessarily state or reftect shose of the United States governient or any agensy thereof.

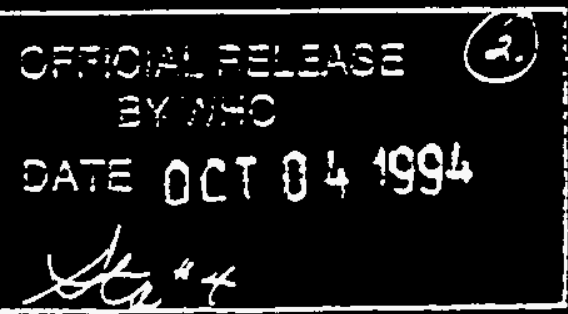

9. Inoper Leval $Q$ 


\section{TABLE OF CONTENTS}

1.0 SCOPE and PURPOSE ....................... . . 3

2.0 TEST PERFORMANCE . . . . . . . . . . . . . . . . . 3

3.0 RECOROS REVIEH ......................... . . 3

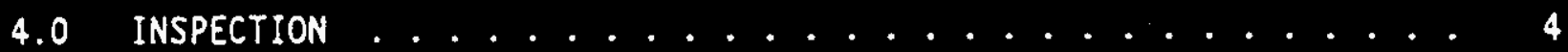

5.0 RUN TEST . . . . . . . . . . . . . . . . . . . . 7

6.0 ACCEPTANCE TEST COMPLETION . . . . . . . . . . . . . . 7

APPENDIX A . . . . . . . . . . . . . . . . . . . . . 8

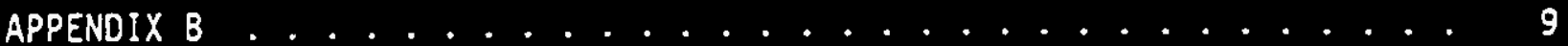

TEST EXCEPTIONS . . . . . . . . . . . . . . . . . . . . 11 


\subsection{SCOPE and PURPOSE}

This acceptance test verifies the requirements specified in WHC-S-0249 Rev. I and ECN 606112 for a Portable, Self-Contained Nitrogen Supply are satisfied.

Because of the latest operating requirement changes, modifications which are necessary to comply with the requirements contained in ECN 613531 shall be tested at a later date and the results shall be included in the Acceptance Test Report.

\subsection{TEST PERFORMANCE}

Norco will complete the following test in the order deemed best by Norco personnel at Norco's facility. Westinghouse Hanford Company, (WHC) personnel shall witness all testing and shall perform the inspection portion of this procedure. All steps shall be completed and any exception noted on the attached exception sheet along with the resolution. Norco shall resolve all exceptions with the concurrence of WHC.

\subsection{RECORDS REVIEN}

alk 3.1 The nitrogen storage tank is be a Portable Liquid Nitrogen Tank, Minnesota Valley Engineering (MVE) Liquid Delivery System, Model HLD-1530N with skid mounted hardware.

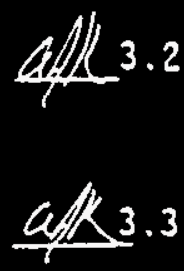

The liquid nitrogen tank is DOT approved for transporting liquid nitrogen under normal working pressure on public roads.

The liquid nitrogen tank was designed and built to the American Society of Mechanical Engineers (ASME) Section 8, Division 1, Boiler and Pressure Vessel Code.

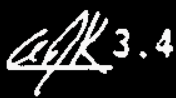

The vaporizing systen is equipped with a pressure regulator. The pressure regulator controls the pressure of the nitrogen gas exiting the vaporizing system. The pressure regulator has a pressure delivery range from 0 to $120 \mathrm{psig}$, when the flow rates range from 0 to 60 scfill. 50 to 150 psigrange is aceeptable beecense oferation is at 120 psig. Fow demenstented, alf

See Extopto 3

The vaporizing system will operate under maximum flow, when severe ambient conditions occur, for a minimum of 16 hours before refueling or servicing is required.

seestion 3.6

The fuel used to operate the vaporizing system is propane and a suitably sized tank is supplied and attached to the trailer. Minimum of 16 hours of continuous operation. 


\subsection{INSPECTION}

4.1 Record the model and serial numbers of the Nitrogen Storage Tank, Vaporizer, and Trailer.

\begin{tabular}{|c|c|c|}
\hline TANK & VAPORIZER & TRAILER \\
\hline Modell $H L D-1530-55-250$ & Model FCLR $6 \times 6 \times 21 /$ Proma & Model: Tret max \\
\hline serial* $\quad 149$ & sorial $\times 940421-2$ & venicle: $169 F 527248$ Do65101 \\
\hline
\end{tabular}

4.2 The liquid nitrogen tank and all other pressure vessels have been stamped to indicate conformance with the American Society of Mechanical Engineers (ASME) Section 8, Division 1, Boiler and Pressure Vessel Code.

\section{Q.124.2.1 Nitrogen Tank}

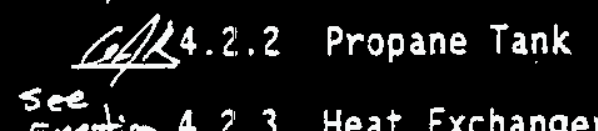

Exeption 4.2.3 Heat Exchanger/Vaporizer

N/A 4.2.4 other

4.3 The Nitrogen Tank has sufficient operating controls and instrumentation to insure safe operation and transportation.

alk 4.3.1 Pressure building

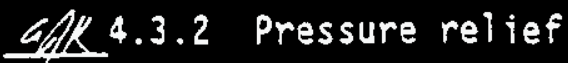

Q $4 \mathbb{K}^{4.3 .3}$ Liquid level indication

ald 4.3.4 Pressure indication

lelk4.3.5 other Fill capability

a/K 4.4 The Nitrogen Tank's controls and operations are fully selfcontained (requiring no auxiliary power or auxiliary support vehicles.)

CM 4.5 The power required to operate the vaporizer is supplied by a propane powered, $4 \mathrm{KW}$ generator. The capability of being either powered from an external source or the propane generator is available through a suitable receptacle/plug arrangement.

4.6 The vaporizer has sufficient operating controls and instrumentation to ensure safe operation including but not limited to the following.

GlK 4.6.1 Water temperature indication

a/R 4.6.2 Nitrogen outlet temperature indication 


\section{See eximen 4.6 Pressure indication}

SPK 4.6.4 Water flow indiestion Internal DP antomatic shutdown GX 4.6.5 Emergency shutdown

G) 4.6.6 Outlet pressure regulator

See 4.6 .7 Vent valve

Exasth 4.6.8 other Pressure Relief of $N_{2}$ on Vaporizer

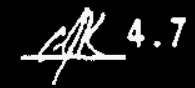

Verify During

Insption 4.8

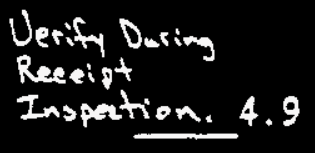

Seretion 4.11

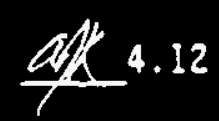

Serserion 4.13
The vaporizing systen's propane fueled water heaters have automatic lighting starters.

A 1 inch inside diameter, 100 foot long, flexible hose is connected to the outlet of the Nitrogen pressure regulator. The flexible hose is rated for pressures of at least 250 psig and temperatures from $-40^{\circ} \mathrm{F}$ to $150^{\circ} \mathrm{F}$. The free end of the hose is equipped with a Hansen LL12-H46 socket. The hose is on a manually operated hand crank hose ree? which is mounted on the tongue assembly. 250 psig

Two additional 50 foot sections of 1 inch inside diameter flexible hose are supplied. The 50 foot sections of hose are equipped with a Hansen LL12-K46 plug on one end and a Hansen LL12-H46 socket on the other end. The hose is rated for pressures of at least $250 \mathrm{psig}$ and temperatures from $-40^{\circ} \mathrm{F}$ to $150^{\circ} \mathrm{F}$. Verify upon Receipt inspextion.

The trailer is a flatbed, 36,000 pound rating, with a load capacity of 30,000 pounds, (See nameplate attached.) Trail Max Model TO-30-F.

Grating is provided for the trailer mounted hoses and piping to prevent damage from personnel climbing on the unit for operation and maintenance. The grating is bolted in place so that it may be removed for maintenance.

All major components are bolted to the trailer for ease of removal and maintenance.

There are no suspect fasteners on the trailer, vaporizer or components. Refer to the Suspect Fasteners Headmark List included in the specification, WHC-5-0249.

4.14 A] components and controis necessary for operation or safety are uniquely identified with a high impact plastic label with $1 / 8$ inch tall characters, Black on a White background.

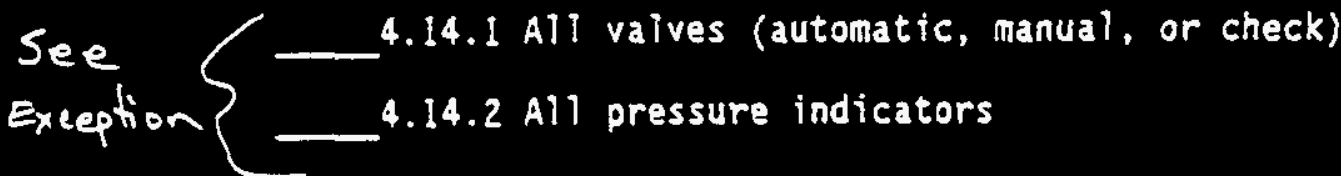




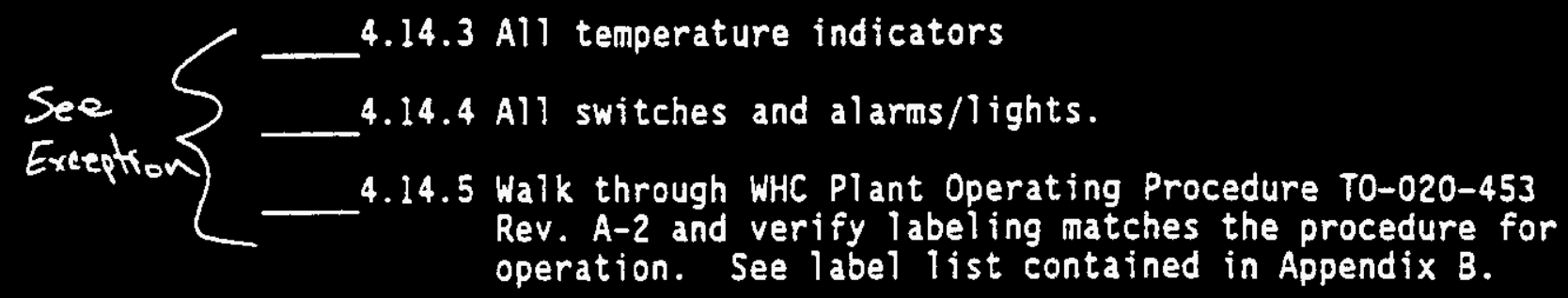

4.15 Trailer Requirements

G/2 4.15.1 Mainframe and platform are manufacturer's standard a/R 4.15 .2 Crossmembers - 20 inch center maximum

QM/R4.15.3 Hitch - Pintle type, adjustable, minimum 2-3/4 inch.

See 4.15 .4 Main Jack - Screw type w/drop foot, 12,000 pound capacity.

See Expeta 4.15.5 Leveling Jacks - Screw type w/drop foot, 12,000 pound capacity (all four corners).

GIll 4.15 .6 Safety chains with hooks.

Q4.14 4.15.72 Axies - 15,000 pound each.

Q1/K 4.15.8 Brakes - 4 wheel air brakes.

a/k 4.15.9 Hubs - 0 il bath type 10 on $8.75 \mathrm{BC}$.

a/K 4.15.10 Suspension - 3 point sipper spring type.

CLK 4.15.11 Wheels - Dual Disc $17.5 \times 6.7510$ on $8.75 \mathrm{BC}$.

Q.ef 4.15 .12

CAk $^{4.15 .13}$

$\underline{6} 4.15 .14$

CIA 4.15 .15

CIP 4.15 .16

Co/4 4.15 .17

Snetion 4.15 .18
8 Tires - 215/75R 17.5 radial load range "H".

Electrical - ICC/DOT approved, sealed system rubber isolated.

Decking - 3/16 inch minimum diamond plate deck.

Paint - Unit is painted with White enamel.

The bottoln of the trailer is undercoated for rust protection.

The equipment is arranged on the trailer for weight distribution and ease of operation.

Verify Flammable Gas placard is on the trailer as required by Dot for the Propane. 


\subsection{RUN TEST}

Norco personnel shall perform this portion of the Acceptance test per their submitted Functional Test Procedure included as Appendix A. WHC personnel shall witness the Functional Test. A minimum of 50 feet of hose shall be connected to the outlet of the flowmeter during testing to simulate WHC operational conditions.

The following data as a minimum shall be recorded to document compliance with the requirements. Recommended to record data on intervals of approximate 5 minutes until relatively steady state conditions are achieved. System stability indicates the equipment will operate continuousiy at each setting.

5.1 Actual pressures of the Nitrogen exiting system with the regulator set at approximately $60,80,100$ and 120 psig. (Final set point of 120 psig is desired.)

5.2 Nitrogen flow rates of $10 \mathrm{scfm}, 50 \mathrm{scfm}$ and the maximum achievable at each pressure setting.

5.3 Temperature of the Nitrogen at the flowmeter installed for testing purposes for each flow rate.

5.4 Vaporizer water temperature.

5.5 Ambient Temperature at the start and end of testing.

\subsection{ACCEPTANCE TEST COMPLETION}

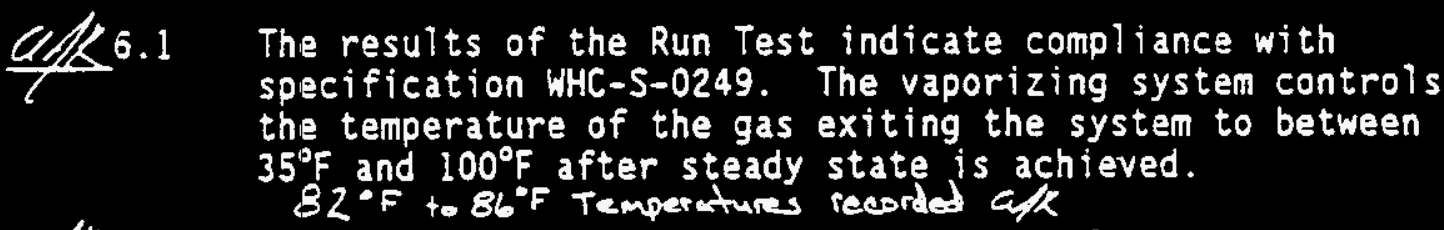

afK 6.2 All portions of this test have been completed.

TEST COMPLETED BY:

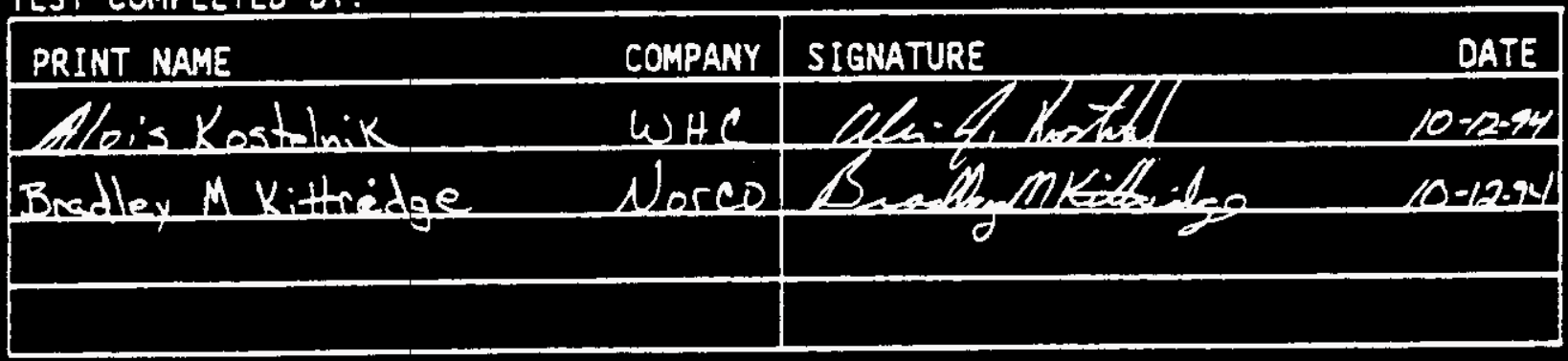


APPENOIX A

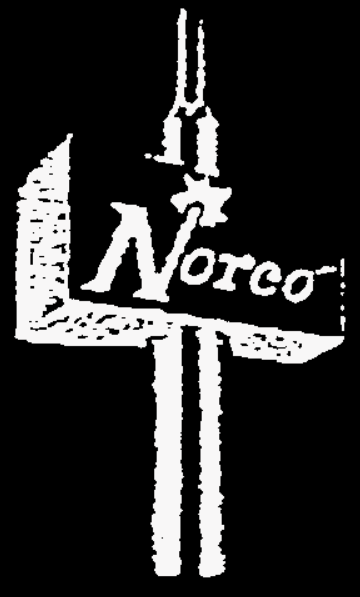

WELDING, SAFETY, MEDICAL GASES AND SUPPLIES

Bestiaghouse fasford

P.0. $20 \times 1970$

Ricalusd, th 99352

Re: Fasetioanl Test Rrocoduses

7.0. $1010 \mathrm{x}-\mathrm{xW}^{2}-404870$

HF. Deie thitworth, Tollowiag vill be the procedure for restiag the Fitregen Unit and Vaporizer as our Bolse loenzion.

1) Fill unit wish all soquized soogunbles, aitzogea, propune and buel for gesarater.

2) Jutr propune syaran as and start poror generator.

3) Start vapozizez alleriag wates 80 efrenlate.

4) Tura pressuze buildiag assembly oa to baild pressure is the aitzogen cask, and stage liquid aissogen glor.

5) Adjuse pressure geguleser os vaporizes fros o - 220 BSIG. cheth flow gases frow 0 - 60 sert.

6) Cheet cemperature of gas exitiog the systam and assure the zasse is betrees $355^{\circ} \mathrm{I}$ so $100^{\circ} \mathrm{T}$.

Thanis you,

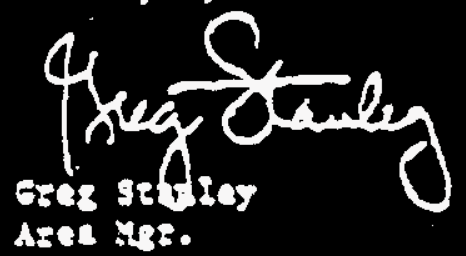




\section{APPENDIX 8}

LABELS ON NITROGEN TRAILER HO-74-5170. ADDITIONAL UNITS TO HAVE IDENTICAL LABELING TO EXTENT POSSIBLE. LABELING SHOULD BE ON $1^{\prime \prime} \times 2^{n}$ OR $1^{\prime \prime} \times 3^{\prime \prime}$ PLASTIC WITH BLACK LETTERS ON A WHITE BACKGROUND. MINIMUH LETTER SIZE $1 / 8^{n}$.

\begin{tabular}{|c|c|c|}
\hline $\begin{array}{c}\text { V-6 } \\
\text { NITROGEN SUPPLY }\end{array}$ & $\begin{array}{l}\text { RV-4 } \\
\text { SUPPLY LINE RELIEF }\end{array}$ & $\begin{array}{c}\text { V-5 } \\
\text { PRESSURE BUILDING }\end{array}$ \\
\hline $\begin{array}{c}V-1 \\
\text { TOP FILL }\end{array}$ & $\begin{array}{c}V-2 \\
\text { BOTTOM FILL }\end{array}$ & $\begin{array}{c}V-3 \\
\text { VENT TANK }\end{array}$ \\
\hline $\begin{array}{c}V-4 \\
\text { LIQUID OELIVERY }\end{array}$ & $\begin{array}{c}V-12 \\
\text { ROAD RELIEF }\end{array}$ & $\begin{array}{c}V-8 \\
\text { FULL TRYCOCK }\end{array}$ \\
\hline $\begin{array}{l}\text { R-I } \\
\text { PRESSURE BUILDING } \\
\text { REGULATOR }\end{array}$ & $\begin{array}{c}V-13 \\
\text { ANNULUS } \\
\text { EVACUATION } \\
\end{array}$ & $\begin{array}{c}V-7 \\
\text { OELIVERY HOSE } \\
\text { DRAIN } \\
\end{array}$ \\
\hline $\begin{array}{l}\text { SOV-1 } \\
\text { NITROGEN SUPPLY } \\
\text { SOLENOID }\end{array}$ & $\begin{array}{c}\text { R-2 } \\
\text { NITROGEN SUPPLY } \\
\text { REGULATOR } \\
\end{array}$ & $\begin{array}{c}\text { PG-2 } \\
\text { NITROGEN SUPPLY } \\
\text { PRESSURE } \\
\end{array}$ \\
\hline VENT NITROGEN & $\begin{array}{c}V-14 \\
\text { TRUCK NITROGEN }\end{array}$ & $\begin{array}{c}V-15 \\
\text { EXHAUSTER NITROGEN }\end{array}$ \\
\hline $\begin{array}{c}\text { R-3 } \\
\text { INSTRUMENT AIR } \\
\text { REGULATOR } \\
\end{array}$ & $\begin{array}{c}V-17 \\
\text { TANK LIQUID } \\
\text { PROPANE }\end{array}$ & $\begin{array}{c}\text { V-18 } \\
\text { EXCHANGER LIQUID } \\
\text { PROPANE }\end{array}$ \\
\hline $\begin{array}{l}V-21 \\
\text { LEFT HEATER } \\
\text { PROPANE }\end{array}$ & $\begin{array}{c}V-20 \\
\text { EXCHANGER PROPANE } \\
\text { GAS }\end{array}$ & $\begin{array}{c}V-19 \\
\text { TANK PROPANE } \\
\text { GAS } \\
\end{array}$ \\
\hline $\begin{array}{c}\text { V-22 } \\
\text { RIGHT HEATER } \\
\text { PROPANE } \\
\end{array}$ & $\begin{array}{l}\text { R-4 } \\
\text { HEATER PROPANE } \\
\text { REGULATOR } \\
\end{array}$ & $\begin{array}{l}\text { TC-1 } \\
\text { NITROGEN TEMP } \\
\text { CONTROLLER } \\
\end{array}$ \\
\hline $\begin{array}{c}\text { RV-6 } \\
\text { PROPANE RELIEF } \\
\end{array}$ & $\begin{array}{l}\text { FS-1 } \\
\text { WATER FLOW SENSOR }\end{array}$ & $\begin{array}{l}\text { TS-1 } \\
\text { WATER TEMP SENSOR }\end{array}$ \\
\hline $\begin{array}{l}\text { V-23 } \\
\text { WATER VENT }\end{array}$ & $\begin{array}{c}V-24 \\
\text { WATER VENT }\end{array}$ & $\begin{array}{l}V-25 \\
\text { WATER VENT }\end{array}$ \\
\hline $\begin{array}{l}\text { FR-1 } \\
\text { WATER FLOW } \\
\text { REGULATOR } \\
\end{array}$ & $\begin{array}{l}\text { RV-5 } \\
\text { OELIVERY HOSE } \\
\text { RELIEF }\end{array}$ & $\begin{array}{l}\text { RV-7 } \\
\text { WATER EXCHANGER } \\
\text { RELIEF } \\
\end{array}$ \\
\hline $\begin{array}{l}\text { WATER PUMP } \\
\text { OFF } \quad \text { ON }\end{array}$ & $\begin{array}{c}\text { V-27 } \\
\text { ANTIFREEZE ORAIN }\end{array}$ & 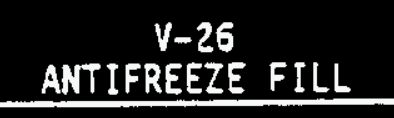 \\
\hline $\begin{array}{c}V-28 \\
\text { GENERATOR PROPANE } \\
\text { GAS }\end{array}$ & & \\
\hline
\end{tabular}


WHC-SD-WM-ATR-108

Rev. 0

Appendix A-12 of A-20

\begin{tabular}{|c|c|c|}
\hline $\begin{array}{c}\text { NITROGEN GAS TEMP } \\
\left.\text { LOW CUTOFF ( }{ }^{\circ} \mathrm{F}\right)\end{array}$ & $\begin{array}{c}\text { WATER TEMP } \\
\text { LOW CUTOFF ( }{ }^{\circ} \text { ) }\end{array}$ & $\begin{array}{c}\text { EMERGENCY } \\
\text { SHUTOOWN }\end{array}$ \\
\hline LEFT HEATER & RIGHT HEATER & CONTROL PANEL \\
\hline POWER ON & WATER PUMP ON & FAULT \\
\hline
\end{tabular}




\begin{tabular}{l|l} 
Step & Description of exception and resolution. \\
\hline $4.2,3$ & No ASME Stamp. Noren shall doanment compliance with \\
\hline & ASME Boiler - Pressure Uassel Code section 8 as required
\end{tabular}
$4,6,3$ No $N_{2}$ Ontlet Pressure Indication. Norco shall install pressure indication at epse reel supply value (upstream) $4,6,8$ No Pressure Ralief an No Vaporizer, Noreo shall install Safety Pressuse Relief on Uaparizer as per vessel pressuse requirements, 4.ll Propane Relief line unsupported. Noreo to add support.

$4.15,18$ Placards ast wistalled Norco to install per Nor requirements.

4,14 Labeling not complete Norco aot supplied with labal soheme prior to $10-41-94$. To be completed and verified at a later date, closed 4,15,4 4,15,5 cant verify w/ont records. Nosco to supply vendor alk information to show anck capacity.

4.13 i Bolts on the $24 x$ supports aremsuspente Bolts shall be replaced by Nocare

$3.5+3.6$ Documentation not available. Norce shall provide the documentation for propane cansumption nter and tank capacities for generator and heaters

EXCEPTION AND RESOLUTION CONCURRENCE:

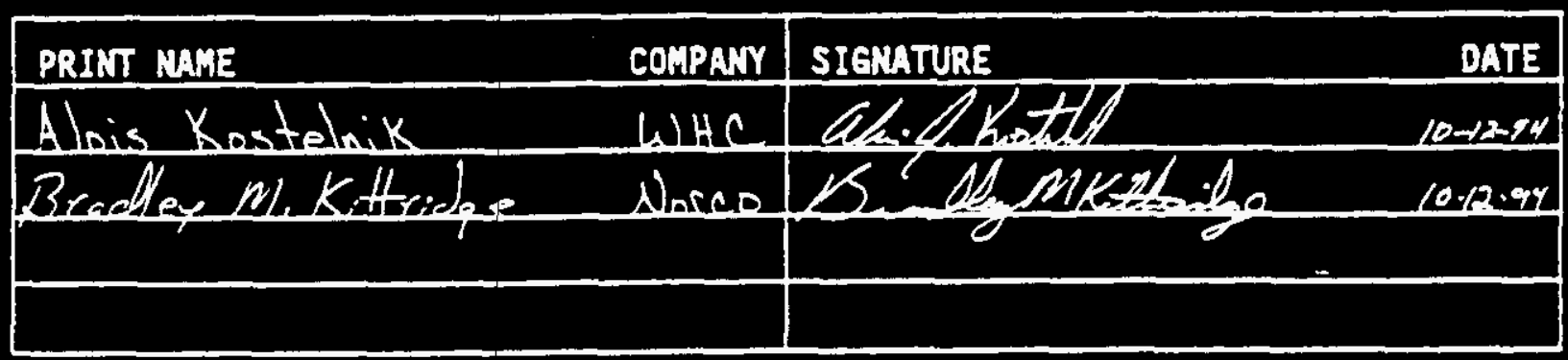

* Make additional copies as required. 
TEST EXCEPTIONS

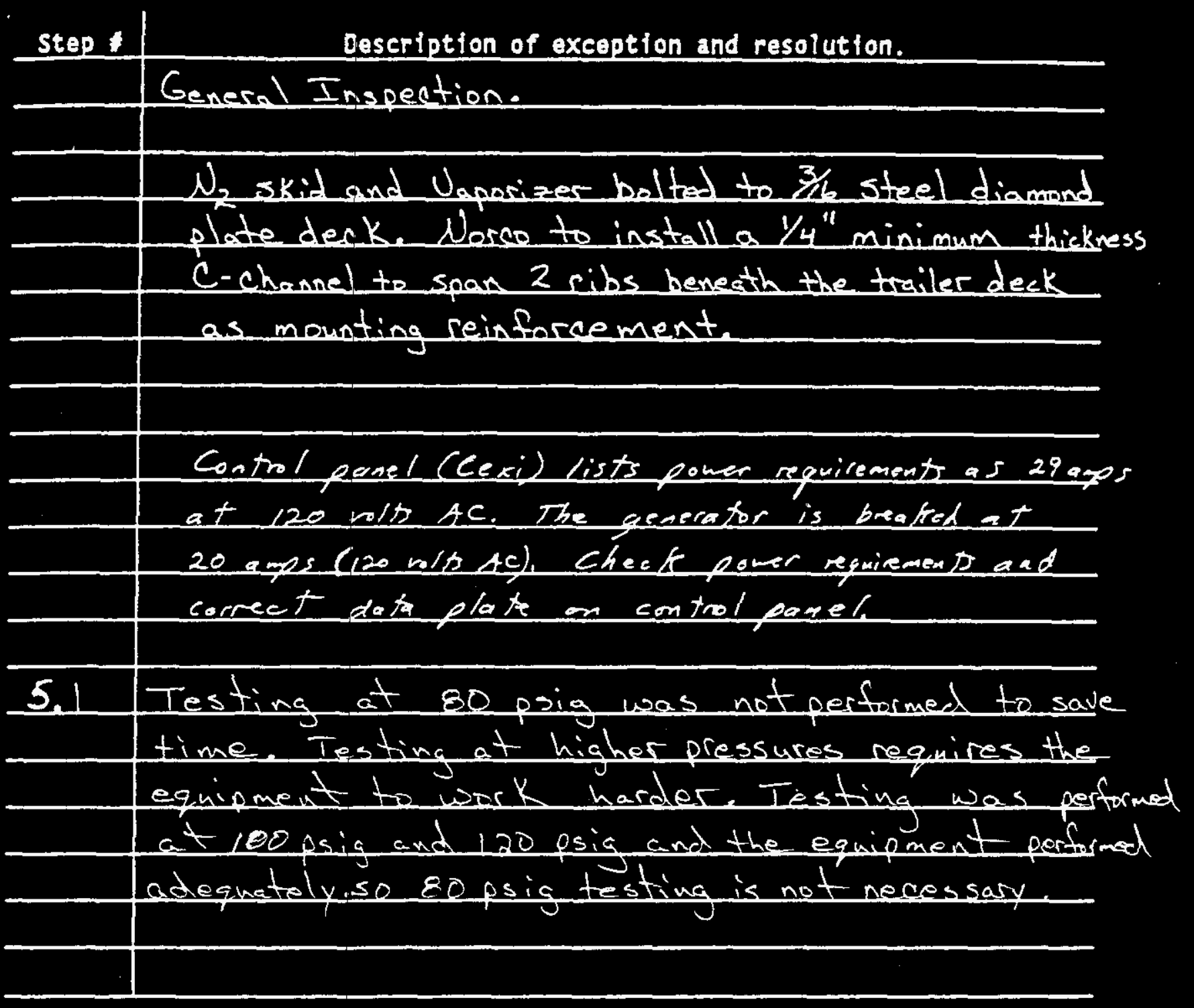

EXCEPTION AND RESOLUTION CONCURRENCE:

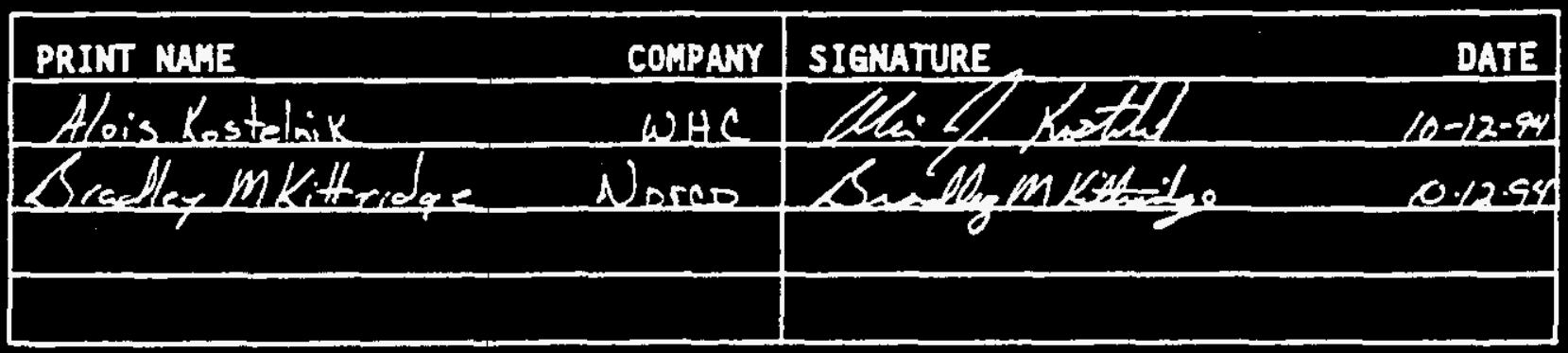

- Make additional coptes as required. 


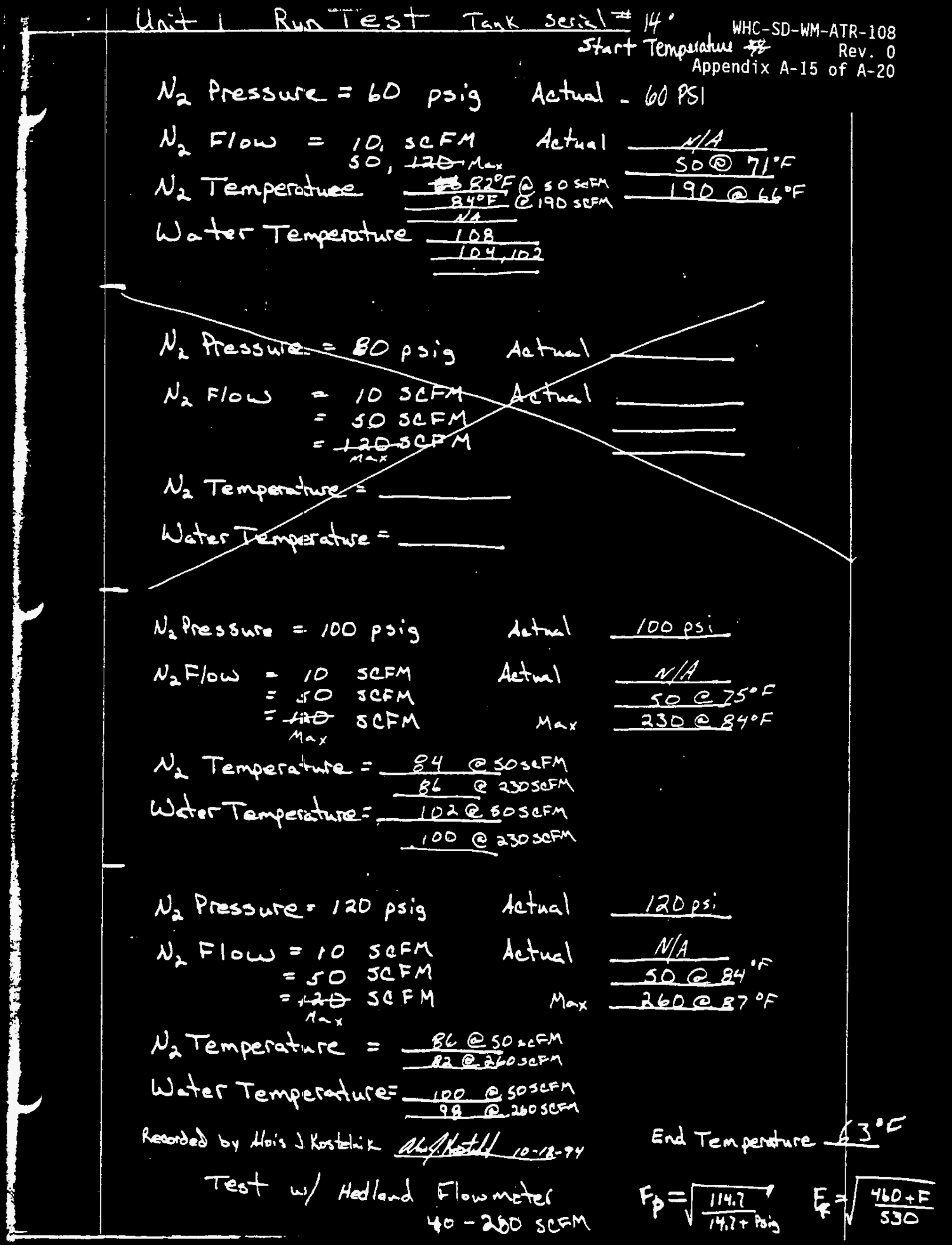




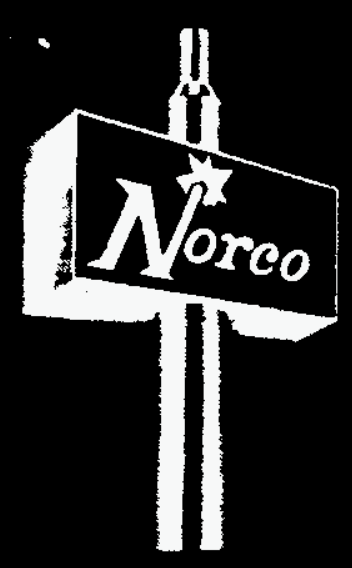

WHC-SD-WM-ATR-108

Rev. 0

Appendix A-16 of A-20

\section{WELDING, SAFETY, MEDICAL GASES AND SUPPLIES}

1121 West Amity Road , Boise, Idaho 83705 ,

(208) 336-1643 •

FAX (208) 384-1720

Reference: WHC-DS-WM-STP-108

Norco Revise Exception Lists

TANK

HLD-1530-SS-250

$\# 149$
VAPORIZER

FCWBLX6X21/Propane

$\mathrm{X} 940421-2$

\section{TRAILER}

Trail Max

169FS2724RA065101

STEP \#
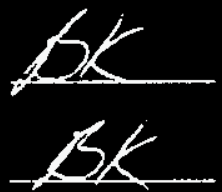

4.6 .3

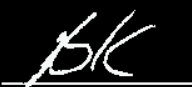

4.6 .8

4.11

4.15 .18

4.14

4.15.4

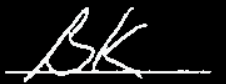

4.13

D大C 3.5

3.6

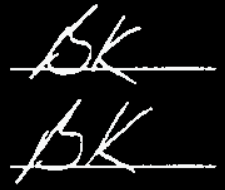

ASME Stamp Supplied

N2 Outlet Pressure Indicator Installed

N2 Safety Relief Mounted

Additional Support Added to Propane Vent Line

DOT Placards Installed on Propane Tank

Labeling Complete as per Appendix B page $9 \& 10$

Documentation Complete / See Attached

All Suspect Fasteners We Charged According to Spec.

Documentation Complete / See Attached

Documentation Completes / See Attached

23" Channel Are Spannedon Cross Member and Welded to support N2 Skis and Vaporizers.
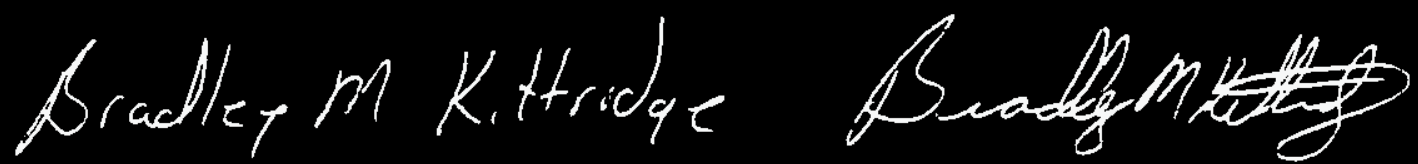
100 West Easy Street. Simi Valley, CA $\$ 3065$

Phone (805) 520-8631

Toll Free 1-800-FOA-CEXI

Facsimile (805) 520-8640

Horco

1121 Reat Amity Road

Bolse, Idaho, 83705

\section{Attn: Brad Rittridge}

Re: CEXI Job No 940421 - Norco P.O. 28765

Brad;

This letter is to confirm that the total propane flow with the unit vaporizing 25,000 scfh of nitrogen and 325 scfh of prppane will be 197 cubie feet of propane per hour. That equates 50 (5.78 gallons per hour of propane. For the unit to operate at full flow for 16 hours, the fuel tank would have to be approximately 95 gallone.

The consumption is as follows

Nitrogen vaporization - 25,000 scth Propane flow

$167.5 \mathrm{cfh}$

Generator set 4.3 Kilowatts continuous Propane flow

27.7 efh

Propane Vaporization Reguirement -

$1.59 \mathrm{efh}$

Total Flow

$196.79 \mathrm{cfh}$

The power requirements for the system are as flows.

Controls Including Nater Beaters Water Pump

Total Power Reguired
3 amps, 120 vac

15.8 amps at 120 vac

7.9 amps at 240 vac

18.3 amps at full logd

The generator set is capable of 35 amps at 120 vac full load continuous power generation. The guestion that Westinghouse raised may be based on the receptacle rating. At any rafe wo wil be supplying a new nameplate to reflect the cofrect amperage rating.

On a more positive note, for you at least. It turns out that our purchasing departinent made a error and ordered water heatere that are double the reciulred size. The units should have been tho fodel 255. Instead the model ordered was a 405 . That means that fos the most part, one of the units will be in the stand by mode almos a 11 the time. The fuel consumption on the unite will not be any higher because of this, you just have more water heating capacity thap you will ever need. The only time the second water heater should come 
on 1 s dufling times of extremely cold $\left(-20^{\circ} \mathrm{F}\right)$ amblent temperatures. During cold ambient temperatures, the second water heater should only come on for very short periods of time.

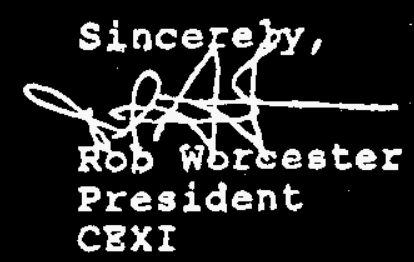




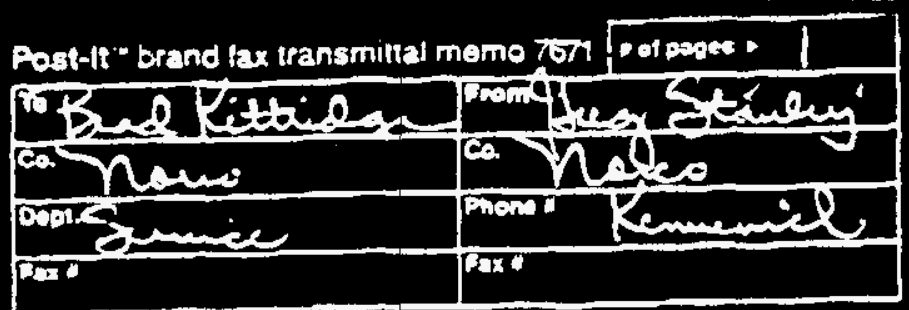

WHC-SD-WM-ATR-108

Rev. 0

Appendix A-19 of A-20

PERFORMER /I 3/8 IN. (9.5MM) I.D. 28R 300 P.S.I. W.P.

TUBS

prantrorcandant

covix:

color

TXMPEXAUUR RANGE

TRE OF BRANDNE
Blended Nitrile.

1 or 2 Textile Braids.

Neoprene.

Aed

$-40^{\circ} \mathrm{F}$ io +180\%

Ink Print.
WORTHC PRXsturs ITE OF COUPLNe
225-300 PSI.

Barbed Insants, Quick

Acting, or Long Shank.

Clamps-Intariocking.

Single Bolt Band, or Wire
Features

- Neoprene cover

- Blended nitrile tube

- Continuous permanent brand

- Wige range of sizes

- Brajd reinforcement
Benefits

- Abrasion, oil, and waather resistant

- Medium oil resistance

- Easy identification

- For many applications

Bater coupling relention for impulse applications
Morkirets

Accembly/Manutecturers

Constiuetion Industry

Forest Industry

Metal Working

Mining

Ship Building

Flastic Molding
Applications

Preumavic cools on production line

Provide power to air operated equipment. Convey air and water.




Author: Alois J (Al) Rostelnik at wre339

WHC-SD-WM-ATR-108

Rev. 0

$12 / 12 / 94 \quad 10: 20 \mathrm{AM}$

Priority: Urgent

TO: Dale $\mathrm{R}$ Whitworth at whC.2

CC: Jeffery C Akere at mith 5

CC: Andrew $P$ Mousal at - HAC216

CC: Alois J (Al) Kostelnik

CC: Jeffory I Smalley at waC340

CC: Roy $J$ Blanchard at mitac340

Subject: Po 404870:Nitrogen Trailer from Norco.

In addition to the correction to the name plate on the vaporizer the following changes are necessary. The breaker, wiring, and receptacle amperage need to be increased to comply with the 1993 National Flectric Code. Article 210-22 of the 1993 N:C requires continuous loads use less than $80 \%$ of the total ampere capacity of the electrical circuit rating.

The specified system power requirement is stated in the CSXI letter to Norco as 18.8 amps. The 20 amp receptacles powered from the 20 amp breaker on the generator are undersized, per the NBC these items should not be used for continuous loads in excess of 16 amps. WHC suggest using a 30 anp breaker, receptacle and plug (NEMA L5-3OR and NEMA L5-30P combination). A wiring upgrade may also be required to ensure 30 anp capability.

The ASMs stamps for the vaporizer must be attached to the pressure vessel pex the ASME code. Another member in my group is returning the Asur atamps to you today so you can return them to Norco for attachment.

I am preparing a receipt inspection plan right now for PQs to perform inspection at Norco and allow them to be paid for the work they have completed thus far. I will let you know as soon as it is complete.

Al Kostelnik 373-0788 
RELEASE AUTHORIZATION

\begin{tabular}{|ll|}
\hline Document Number: & WHC-SD-WM-ATP-108, REV 0 \\
\hline Document Title: & $\begin{array}{l}\text { Acceptance Test Procedure for a Portable, Self- } \\
\text { Contained Nitrogen Supply }\end{array}$ \\
\hline Release Date: & October 4, 1994 \\
\hline
\end{tabular}

This document was reviewed following the procedures described in WHC.CM-3-4 and is:

APPROVED FOR PUBLIC RELEASE

WHC Information Release Administration Specialist:

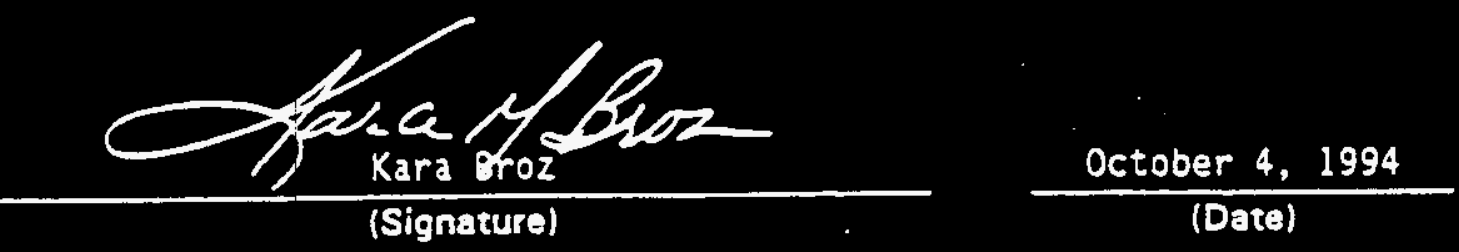


2. To: (Receiving Organization)

Core Sampling

5. Proj./Pros./Dept./0iv.:

Core Sampling Aux. Equipment

8. Originator Remarks:

ETN-94-0023-F

This Acceptance Test Procedure is transmitted for approval. A portion of the procedure was prepared by the Seller and will be performed at the Sellers location. The ATP will show compliance with specification WHC-S-0249 Rev.I.

11. Receiver Remarks:
Characterization Equipment

6. Cog. Engr.:

J.L. Smalley
3. Fraw: (Originating organization)

6. Reloted EDT No.:

$N / A$

7. Purchase Order No.: 404870

9. Equip./Component KO.:

$N / A$

10. Systea/sidg./Facility:

200 Genera?

12. Major Assas. Dug. Ho.: $N / A$

13. Permit/Permit Applieation No.: $N / A$

14. Required Response Date: $10 / 4 / 94$

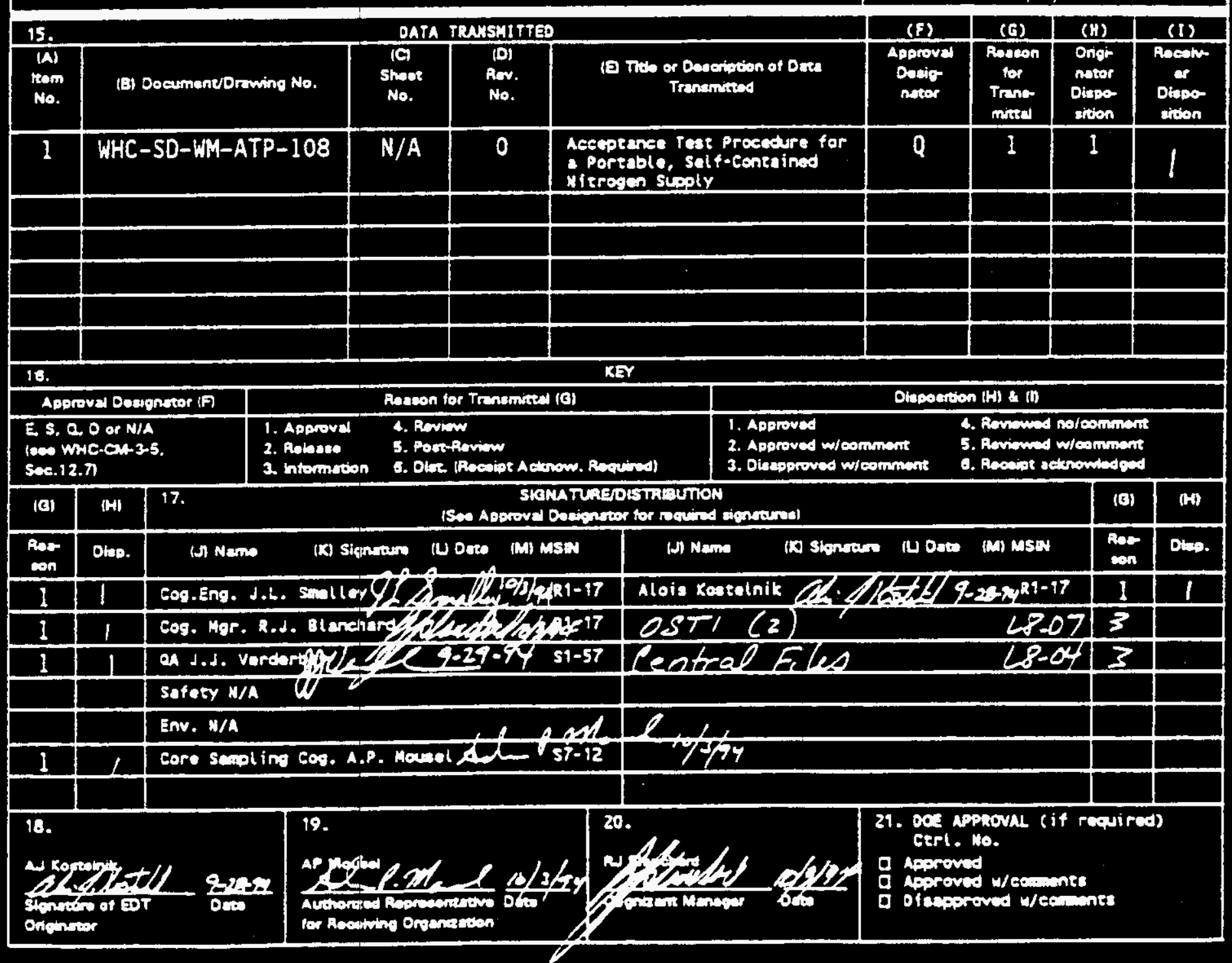

$00-7600-172-2(04 / 96)$ esfogt 


\section{SUPPORTING DOCUMENT}

2. Title
WHC-SD-WM-ATR-108

Rev. 0

Appendix B-3 of B-20

WHC-SD-WM-ATP-108

0

Acceptance Test Procedure for a Portabie, SelfContained Nitrogen Supply

5. Key Words

ETN-94-0023-F

Core Sampling, Nitrogen Trailer, Specification WHC-5-0249, Liquid Nitrogen, Norco, MVE, Minnesota Valley Engineering, Vaporizer, Cryogenic Experts Incorporated, CEXI, Purchase Órder 404870, Eore Sampling Auxiliary Equipment $\rightarrow=0$ -

6. Author

Name: Alois $\mathrm{J}$ Kosteinik

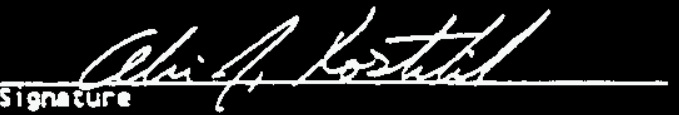

Organization/chares code

$7 E A 40 / N 4570$

7. abseract Kms $1 \% \% / 8 \%$ PQ

This Acceptance Test Procedure (ATP) wif document compliance with the requirements of WHC-S-0249 Rev.I and ECN 606112. The equipment being tested is a Portable, SelfContained Nitrogen Supply. The unit was purchased as a Design and Fabrication procurement activity. The Functional Test was writen by the Seller and is contained in Appendix A. The Functional test will be performed by the Seller with representatives of the Westinghouse Hanford Company performing inspection and witnessing the functional test at the Seller's location.

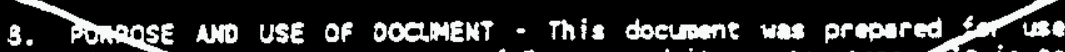
within U.S. Department of Energy and its centractory $1 \mathrm{t}$ is 80 be used bin to perform, direct, or intesers work under U.S. Departament ox Energy eentracts. This doct it is mot aporoved for public retease moib ceviensed.

patent status - This decument ate since it is erananited in advance of patent elearance onde swilable in cenfidense solety for use in parforman of work Uth fontracts with the U.S. Oepartmene of nirgy. This document is not bube pubtished nor its contents or wise disseminesed or used for purposine other than spec if igt wove bofore patent approval for such release or were hes

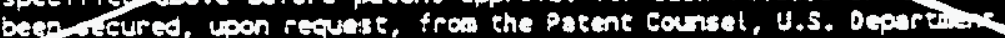
I Energy field office, Richland, $t h$.

Disclutmer - This report was prepared as an aceeune of work spensored by an agency of the Uni ted Stukes Governiment. Nei ther the united states Goverrment: nor any agency shereof, nor any of their etiployees, nor any of thair contraetors, subcontractors or their enployees, wakes amy werranty, expreas or icplicd, or asumes any legal liebility or reaperwibility for the aceursecy, esupteteness, or any third party's we or the results of sueh we of any inforintion, apoaratus, product, or process diselosed, or reprencents thet its wee would not infringe privitely anded rights. Roforence heroin to any spectific centenreial product, process, or service by trade nom,

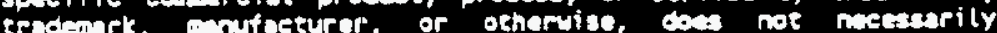

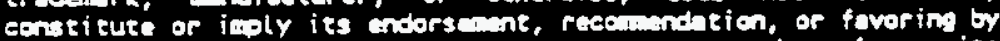
the United states covernbent or any egency thereof or its eoneractors or subenervetors. The views and coinions of suthors expressed herein $\$$ not nesessarily seate or reflect these of the United states Goverrmint or any agensy thereaf.

10.

RELEASE STAMP

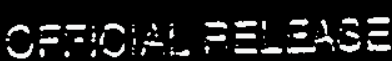

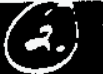

BY:?

DATE OCT 4 1994

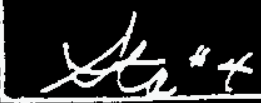

ค. Imoaet level Q 
TABLE OF CONTENTS

1.0 SCOPE and PURPOSE ...................... 3

2.0 TEST PERFORMANCE . . . . . . . . . . . . . . . . . . . 3

3.0 RECORDS REVIEH . . . . . . . . . . . . . . . . . . . 3

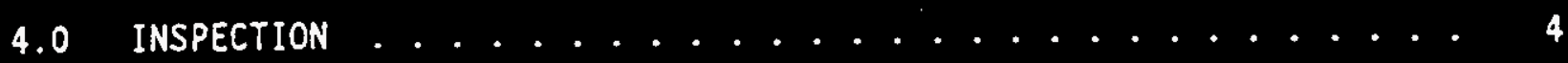

5.0 RUN TEST . . . . . . . . . . . . . . . . . . . . 7

6.0 ACCEPTANCE TEST COMPLETION . . . . . . . . . . . . . . . 7

APPENDIX A . . . . . . . . . . . . . . . . . . . . . . 8

APPENDIX B . . . . . . . . . . . . . . . . . . . . . . . . . 9

TEST EXCEPTIONS . . . . . . . . . . . . . . . . . . . 11 


\subsection{SCOPE and PURPOSE}

This acceptance test verifies the requirements specified in WHC-S-0249 Rev. I and ECN 606112 for a Portable, Self-Contained Nitrogen Supply are satisfied.

Because of the latest operating requirement changes, modifications which are necessary to comply with the requirements contained in ECN 613531 shall be tested at a later date and the results shall be included in the Acceptance Test Report.

\subsection{TEST PERFORMANCE}

Norco will complete the following test in the order deemed best by Norco personnel at Norco's facility. Westinghouse Hanford Company, (WHC) personnel shall witness all testing and shall perform the inspection portion of this procedure. All steps shall be completed and any exception noted on the attached exception sheet along with the resolution. Norco shall resolve all exceptions with the concurrence of WHC.

\subsection{RECORDS REVIEW}

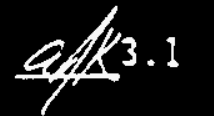

The nitrogen storage tank is be a Portable Liquid Nitrogen Tank, Minnesota Valley Engineering (MVE) Liquid Delivery System, Model HLO-1530N with skid mounted hardware.

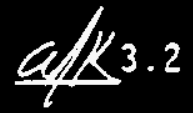

The liquid nitrogen tank is DOT approved for transporting liquid nitrogen under normal working pressure on public roads.

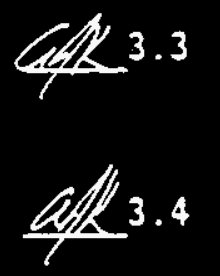

The liquid nitrogen tank was designed and built to the American Society of Mechanical Engineers (ASME) Section 8, Division 1, Boiler and Pressure Vessel Code.

The vaporizing systen is equipped with a pressure regulator. The pressure regulator controls the pressure of the nitrogen gas exiting the vaporizing system. The pressure regulator has a pressure delivery range from 0 to $120 \mathrm{psig}$, when the flow rates range from 0 to 60 scfm. 50 to 150 psig range is accep table because operation is at 120 pans 3 sig. Flow capacity demonstatd, $a / k$

See 3.5 The vaporizing system will operate under maximum flow, when severe ambient conditions occur, for a minimum of 16 hours before refueling or servicing is required.

sesetion 3.6

The fuel used to operate the vaporizing system is propane and a suitably sized tank is supplied and attached to the trailer. Minimum of 16 hours of continuous operation. 


\subsection{INSPECTION}

4.1 Record the model and serial numbers of the Nitrogen Storage Tank, Vaporizer, and Trailer.

\begin{tabular}{|c|c|c|}
\hline TANK & VAPORIZER & TRAILER \\
\hline Modat: HLO-1530-55-250 & Model: FClND $\angle x<x 21 / \mathrm{An}$ & Modeli Tn \\
\hline serial: 148 & Serial $* 940421-1$ & vehiele: T69F52726R1065102 \\
\hline
\end{tabular}

4.2 The liquid nitrogen tank and all other pressure vessels have been stamped to indicate conformance with the American Society of Mechanical Engineers (ASME) Section 8, Division 1, Boiler and Pressure Vessel Code.

a) 4.2.1 Nitrogen Tank

QfK 4.2 .2 Propane Tank

SEE Exception 4.2.3 Heat Exchanger/Vaporizer

M/A 4.2.4 other

4.3 The Nitrogen Tank has sufficient operating controls and instrumentation to insure safe operation and transportation.

4K 4.3.1 Pressure building

CLC 4.3.2 Pressure relief

$\underline{a} 4$ 4.3.3 Liquid level indication

$\mathbb{K}_{4.3 .4}$ Pressure indication

sen Ereeption 4.3.5 other Fill Capability

CSK 4.4 The Nitrogen Tank's controls and operations are fully selfcontained (requiring no auxiliary power or auxiliary support vehicles.)

Q/K 4.5 The power required to operate the vaporizer is supplied by a propane powered, $4 \mathrm{KH}$ generator. The capability of being either powered from an external source or the propane generator is available through a suitable receptacle/plug arrangement.

4.6 The vaporizer has sufficient operating controls and instrumentation to ensure safe operation including but not 1 imited to the following.

a/K 4.6.1 Water temperature indication

a/N 4.6.2 Nitrogen outlet temperature indication 
See exeeptiot.6.3 Pressure indication

Q1K 4.6.4 Water flow indication Internal flow DP sensors provide a/K 4.6.5 Emergency shutdown automatic shutdown. epte

4.6.6 Outlet pressure regulator

afX4.6.7 Vent valve

See excetit4.6.8 Other Pressure Relief of $\mathrm{N}_{2}$ an Vaporizer alk 4.7

Verifyduring 4.8 Inspection. The vaporizing system's propane fueled water heaters have automatic lighting starters.

A 1 inch inside diameter, 100 foot long, flexible hose is connected to the outlet of the Nitrogen pressure regulator. The flexible hose is rated for pressures of at least 250 psig and temperatures from $-40^{\circ} \mathrm{F}$ to $150^{\circ} \mathrm{F}$. The free end of the hose is equipped with a Hansen LL12-H46 socket. The hose is on a manually operated hand crank hose reel which is

Verify during Ieceitt 4.9 mounted on the tongue assembly. 250 psig.

Two additional 50 foot sections of 1 inch inside diameter flexible hose are supplied. The 50 foot sections of hose are equipped with a Hansen LL12-K46 plug on one end and a Hansen LL12-H46 socket on the other end. The hose is rated for pressures of at least $250 \mathrm{psig}$ and temperatures from $-40^{\circ} \mathrm{F}$ to $150^{\circ} \mathrm{F}$.

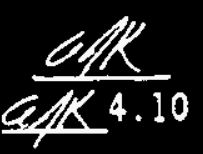
(To be verified upon Receipt Inspection.) The trailer is a flatbed, 36,000 pound rating, with a load capacity of 30,000 pounds, (See nameplate attached.) Trail Max Model TD-30-F.

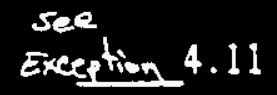

Grating is provided for the trailer mounted hoses and piping to prevent damage from personnel climbing on the unit for operation and maintenance. The grating is bolted in place so that it may be removed for maintenance.

alk 4.12 All major components are bolted to the trailer for ease of removal and maintenance.

Exeeption 4.13

There are no suspect fasteners on the trailer, vaporizer or components. Refer to the Suspect Fasteners Headmark List included in the specification, WHC-S-0249.

4.14 All components and controis necessary for operation or safety are un iquely identified with a high impact plastic label with $1 / 8$ inch tall characters, Black on a White background.






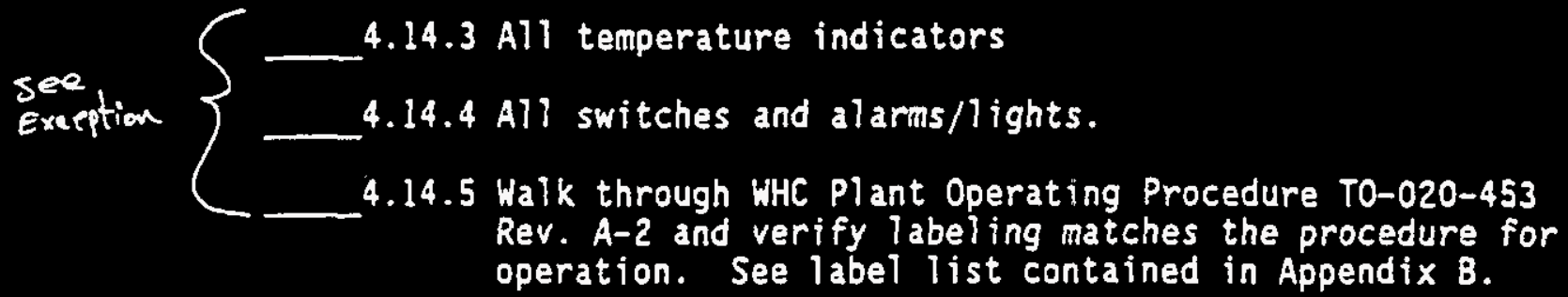

4.15 Trailer Requirements

QW 4.15.1 Mainframe and platform are manufacturer's standard L $4 \mathbb{K}_{4.15 .2}$ Crossmembers - 20 inch center maximum

G/א 4.15.3 Hitch - Pintle type, adjustable, minimum 2-3/4 inch.

See Emetion 4.15.4 Main Jack - Screw type w/drop foot, 12,000 pound capacity.

Soeption 4.15.5 Leveling Jacks - Screw type w/drop foot, 12,000 pound capacity (all four corners).

G/R 4.15.6 Safety chains with hooks.

a/K 4.15.72 Axles - 15,000 pound each.

CIIL 4.15 .8 Brakes $=4$ wheel air brakes.

Cef 4.15 .9 Hubs - 0 il bath type 10 on $8.75 \mathrm{BC}$.

Q1/ 4.15 .10

Suspension - 3 point slipper spring type.

Lath4.15.11

Wheels - Dual Disc $17.5 \times 6.7510$ on $8.75 \mathrm{BC}$.

G.J 4.15 .12

8 Tires - 215/75R 17.5 radial load range " $H$ ".

C4.15.13

Electrical - ICC/DOT approved, sealed system rubber isolated.

G/K4.15.14 Decking - 3/16 inch minimum diamond plate deck.

al/ 4.15 .15

Paint - Unit is painted with thite ename?.

낸.15.16

The botton of the trailer is undercoated for rust protection.

404.15 .17

see

exception 4.15 .18

The equipment is arranged on the trailer for weight distribution and ease of operation.

Verify Flanmable Gas placard is on the trailer as required by DOT for the Propane. 


\subsection{RUN TEST}

Norco personnel shall perform this portion of the Acceptance test per their submitted Functional Test Procedure included as Appendix A. WHC personnel shall witness the Functional Test. A minimum of 50 feet of hose shall be connected to the outlet of the flowmeter during testing to simulate WHC operational conditions.

The following data as a minimum shall be recorded to document compliance with the requirements. Recommended to record data on intervals of approximate 5 minutes until relatively steady state conditions are achieved. System stability indicates the equipment will operate continuously at each setting.

5.1 Actual pressures of the Nitrogen exiting system with the regulator set at approximately $60,80,100$ and 120 psig. (Final set point of 120 psig is desired.)

5.2 Nitrogen flow rates of $10 \mathrm{scfm}, 50 \mathrm{scfm}$ and the maximum achievable at each pressure setting.

5.3 Temperature of the Nitrogen at the flowmeter installed for testing purposes for each flow rate.

$\mathbf{5 . 4}$ Vaporizer water temperature.

5.5 Ambient Temperature at the start and end of testing.

\subsection{ACCEPTANCE TEST COMPLETION}

QR 6.1 The results of the Run Test indicate compliance with specification WHC-S-0249. The vaporizing system controls the temperature of the gas exiting the system to between $35^{\circ} \mathrm{F}$ and $100^{\circ} \mathrm{F}$ after steady state is achieved.

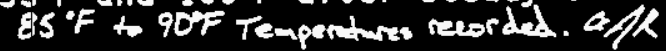

a/K6.2 All portions of this test have been completed.

\section{TEST COMPLETEO BY:}

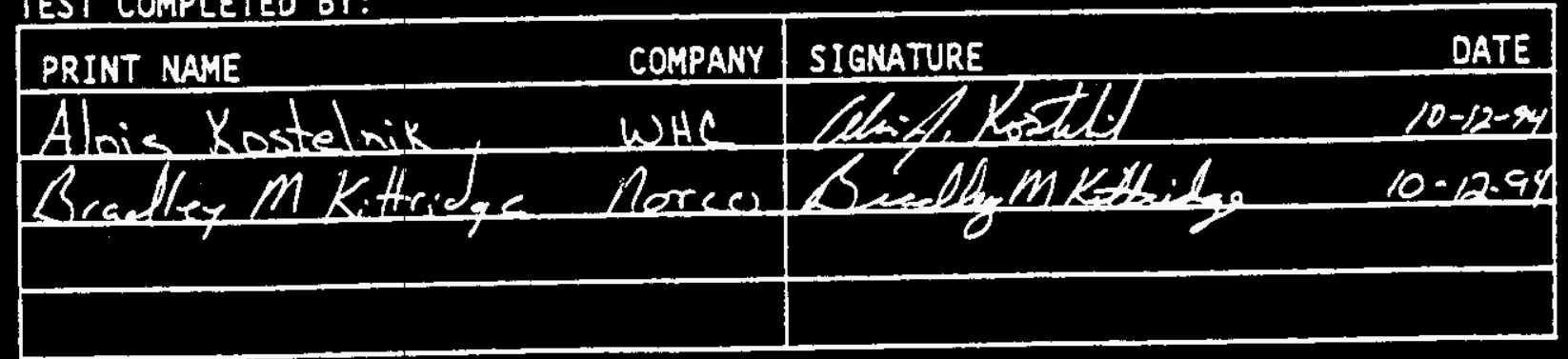


APPENDIX A

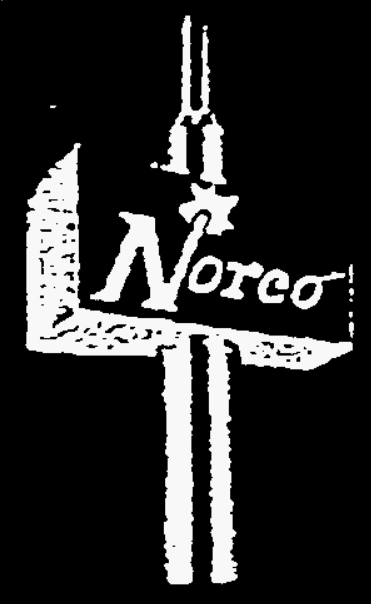

\section{WELDING, SAFETY, MEDICAL GASES AND SUPPLIES}

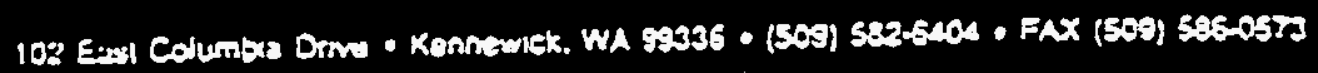

September 22, 1994

veatiazbouse Basford

P.0. $80 \times 1970$

Riebland, th 99352

Re: Fanetionsl Test Proceduses

P.0. $100 x-x 70-404870$

ME. Dale miturerts,

Folloring vill be she procedure for sesting the Fitregen torit

and vaposizer as ous Bolde loention.

1) Eill unis with all soquizad songuables, aitsegas, propane and tual for geacrser.

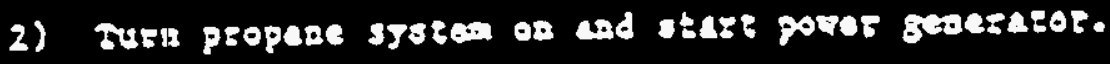

3) Stais vapozizer alloriag water 80 elzerlate.

4) Turn pressage buildiag assembly on to build pressure in be aitzoges rank, and stase liquid airsoger Elow.

5) Adjust pressure regulaser os suporizes ston o - 120 gSto. Gack flow zated kzow 0 - 60 sert.

6) Chetk temperceuse of gas exiting the system and assure the zaspe is bostees $35^{\circ} \mathrm{T}$ so $100^{\circ} \mathrm{T}$.

Stade yor,

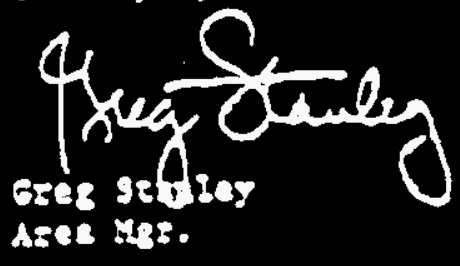


WHC-SD-WM-ATR-108

Rev. 0

Appendix B-11 of B-20

\section{APPENDIX B}

LABELS ON NITROGEN TRAILER HO-74-5170. ADDITIONAL UNITS TO HAVE IDENTICAL LABELING TO EXTENT POSSIBLE. LABELING SHOULD BE ON 1" $\times 2^{\prime \prime}$ OR $1 " x 3^{\prime \prime}$ PLASTIC WITH BLACK LETTERS ON A WHITE BACKGROUND. MINIMUM LETTER SIZE $1 / 8 "$.

\begin{tabular}{|c|c|c|}
\hline $\begin{array}{c}V-6 \\
\text { NITROGEN SUPPLY }\end{array}$ & $\begin{array}{c}\text { RV-4 } \\
\text { SUPPLY LINE RELIEF }\end{array}$ & $\begin{array}{c}\text { V-5 } \\
\text { PRESSURE BUILOING }\end{array}$ \\
\hline $\begin{array}{c}V-1 \\
\text { TOP FILL }\end{array}$ & BOTTOM FILL & $\begin{array}{c}V-3 \\
\text { VENT TANK }\end{array}$ \\
\hline $\begin{array}{c}V-4 \\
\text { LIQUID DELIVERY }\end{array}$ & $\begin{array}{c}y-12 \\
\text { ROAD RELIEF } \\
\end{array}$ & $\begin{aligned} & V-8 \\
& \text { FULL TRYCOCK } \\
&\end{aligned}$ \\
\hline $\begin{array}{c}\text { R-1 } \\
\text { PRESSURE BUILOING } \\
\text { REGULATOR }\end{array}$ & $\begin{array}{c}\text { V-13 } \\
\text { ANWULUS } \\
\text { EVACUATION }\end{array}$ & $\begin{array}{c}V-7 \\
\text { DELIVERY HOSE } \\
\text { DRAIN } \\
\end{array}$ \\
\hline $\begin{array}{l}\text { SOV-1 } \\
\text { NITROGEN SUPPLY } \\
\text { SOLENOID }\end{array}$ & $\begin{array}{c}\text { R-2 } \\
\text { NITROGEN SUPPLY } \\
\text { REGULATOR } \\
\end{array}$ & $\begin{array}{c}\text { PG-2 } \\
\text { NITROGEN SUPPLY } \\
\text { PRESSURE } \\
\end{array}$ \\
\hline $\begin{array}{l}V-16 \\
\text { VENT NITROGEN }\end{array}$ & $\begin{array}{c}V-14 \\
\text { TRUCK NITROGEN }\end{array}$ & $\begin{array}{c}V-15 \\
\text { EXHAUSTER NITROGEN }\end{array}$ \\
\hline $\begin{array}{c}\text { R-3 } \\
\text { INSTRUMENT AIR } \\
\text { REGULATOR } \\
\end{array}$ & $\begin{array}{l}Y-17 \\
\text { TANK LIQUID } \\
\text { PROPANE }\end{array}$ & $\begin{array}{c}V-18 \\
\text { EXCHANGER LIQUID } \\
\text { PROPANE }\end{array}$ \\
\hline $\begin{array}{l}V-21 \\
\text { LEFT HEATER } \\
\text { PROPANE } \\
\end{array}$ & $\begin{array}{c}V-20 \\
\text { EXCHANGER PROPANE } \\
\text { GAS }\end{array}$ & $\begin{array}{l}V-19 \\
\text { TANK PROPANE } \\
\text { GAS }\end{array}$ \\
\hline $\begin{array}{l}\text { V-22 } \\
\text { RIGHT HEATER } \\
\text { PROPANE } \\
\end{array}$ & $\begin{array}{c}\text { R-4 } \\
\text { HEATER PROPANE } \\
\text { REGULATOR } \\
\end{array}$ & $\begin{array}{l}\text { TC-I } \\
\text { NITROGEN TEMP } \\
\text { CONTROLLER }\end{array}$ \\
\hline $\begin{array}{c}\text { RV-6 } \\
\text { PROPANE RELIEF } \\
\end{array}$ & $\begin{array}{l}\text { FS-1 } \\
\text { WATER FLOW SENSOR }\end{array}$ & $\begin{array}{l}\text { TS-1 } \\
\text { WATER TEMP SENSOR }\end{array}$ \\
\hline $\begin{array}{c}\text { V-23 } \\
\text { WATER VENT }\end{array}$ & $\begin{array}{c}\text { V-24 } \\
\text { WATER VENT }\end{array}$ & $\begin{array}{l}\text { V-25 } \\
\text { WATER VENT }\end{array}$ \\
\hline $\begin{array}{l}\text { FR-1 } \\
\text { WATER FLOW } \\
\text { REGULATOR } \\
\end{array}$ & $\begin{array}{l}\text { RY-5 } \\
\text { DELIVERY HOSE } \\
\text { RELIEF }\end{array}$ & $\begin{array}{c}\text { RV-7 } \\
\text { WATER EXCHANGER } \\
\text { RELIEF } \\
\end{array}$ \\
\hline $\begin{array}{r}\text { WATER PUMP } \\
\text { OFF } \\
\end{array}$ & $\begin{array}{c}\text { V-27 } \\
\text { ANTIFREEZE DRAIN }\end{array}$ & $\begin{array}{c}V-26 \\
\text { ANTIFREEZE FILL }\end{array}$ \\
\hline $\begin{array}{c}V-28 \\
\text { GENERATOR PROPANE } \\
\text { GAS }\end{array}$ & & \\
\hline
\end{tabular}


WHC-SD-WM-ATR-108

Rev. 0

Appendix B-12 of B-20

\begin{tabular}{|c|c|c|}
\hline $\begin{array}{c}\text { NITROGEN GAS TEMP } \\
\text { LOW CUTOFF }\left({ }^{\circ} \mathrm{F}\right)\end{array}$ & $\begin{array}{c}\text { WATER TEMP } \\
\text { LOW CUTOFF }\end{array}$ & $\begin{array}{c}\text { EMERGENCY } \\
\text { SHUTOOWN }\end{array}$ \\
\hline LEFT HEATER & RIGHT HEATER & CONTROL PANEL \\
\hline POWER ON & WATER PUMP ON & FAULT \\
\hline
\end{tabular}


TEST EXCEPTIOHS

Step 1 Description of exception and resolution.

$4,2,3$ No ASME Stamp, Noreo shall document compliance with ASME Boiler a Pressure basel ade Section 8 as required.

$4,3,5$ Fill hase disconnected Noran to install hose and velill be verified upon receipt by wte.

$4,6,3$ No $\mathrm{N}_{2}$ Outlet Pressure Indicotion. Nomeo shall install

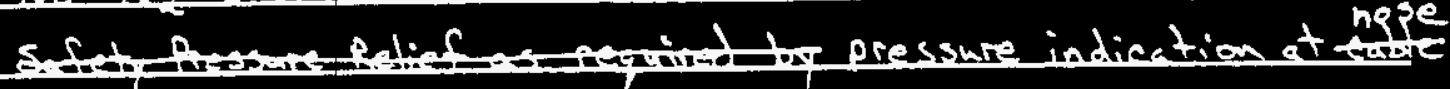
ceel supoly value (upstriam)

4.6 .8 No Vaporieer $\mathrm{N}_{2}$ sefaty Relief, Norae shall install snfety Pressure Relief on Uaporizer per vessel requirments.

4.11 Propane Relief vent line unsupported Norce shall provide additionel support.

4.15 .18 Placards Not installed. Noreo shall install Flammable Gas plaards as required by DOT.

4,14 Labeling not completed Noras was nat supplied with the label schene priec to 10-11-94. To be completed and verified at a laterdate.

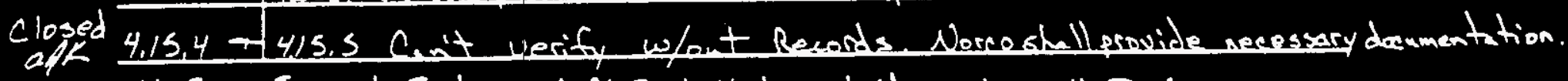

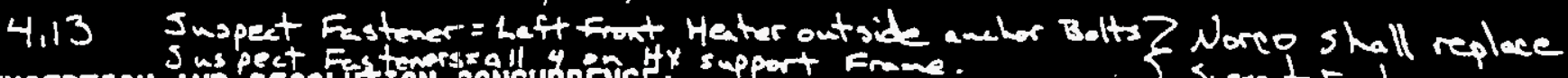

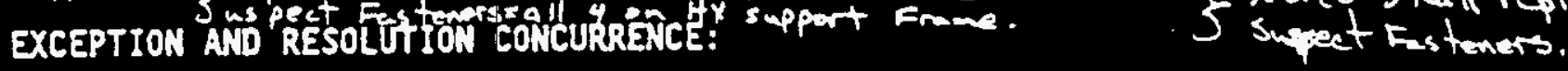

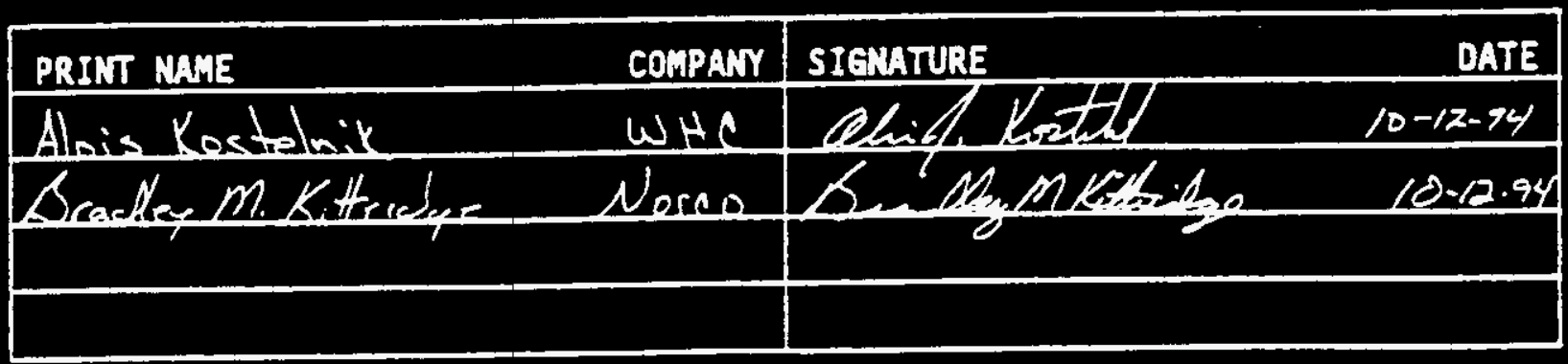

Make additional copies as required. 


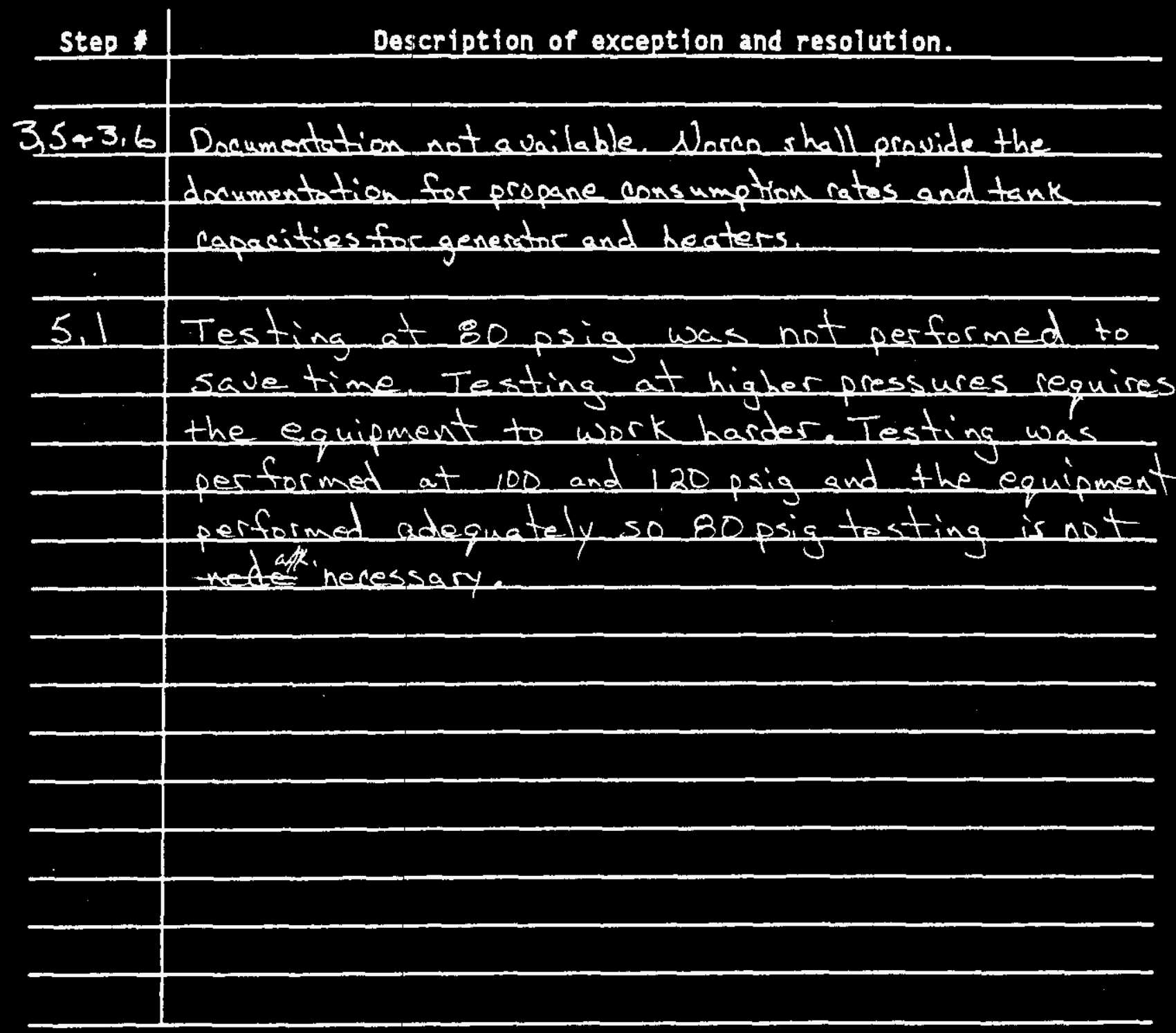

EXCEPTION AND RESOLUTION CONCURRENCE:

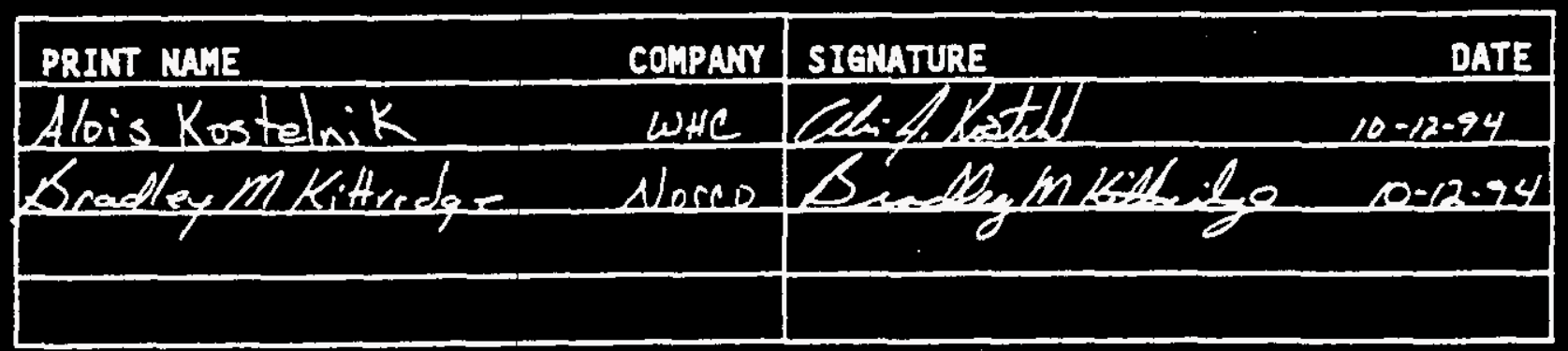

* Make additional coples as required. 




EXCEPTION AN RESOLUTION CONCURRENCE:

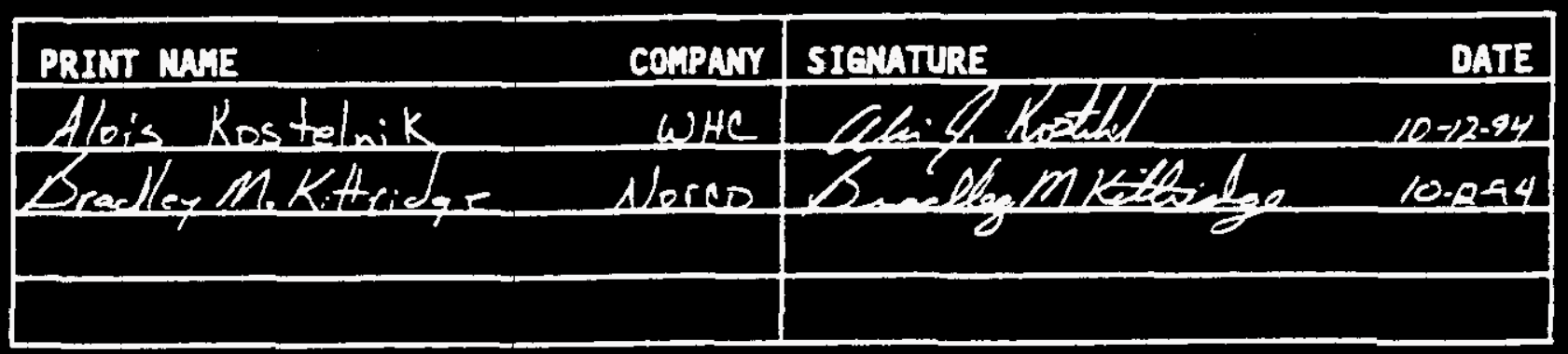

Make additional coples as requtred. 


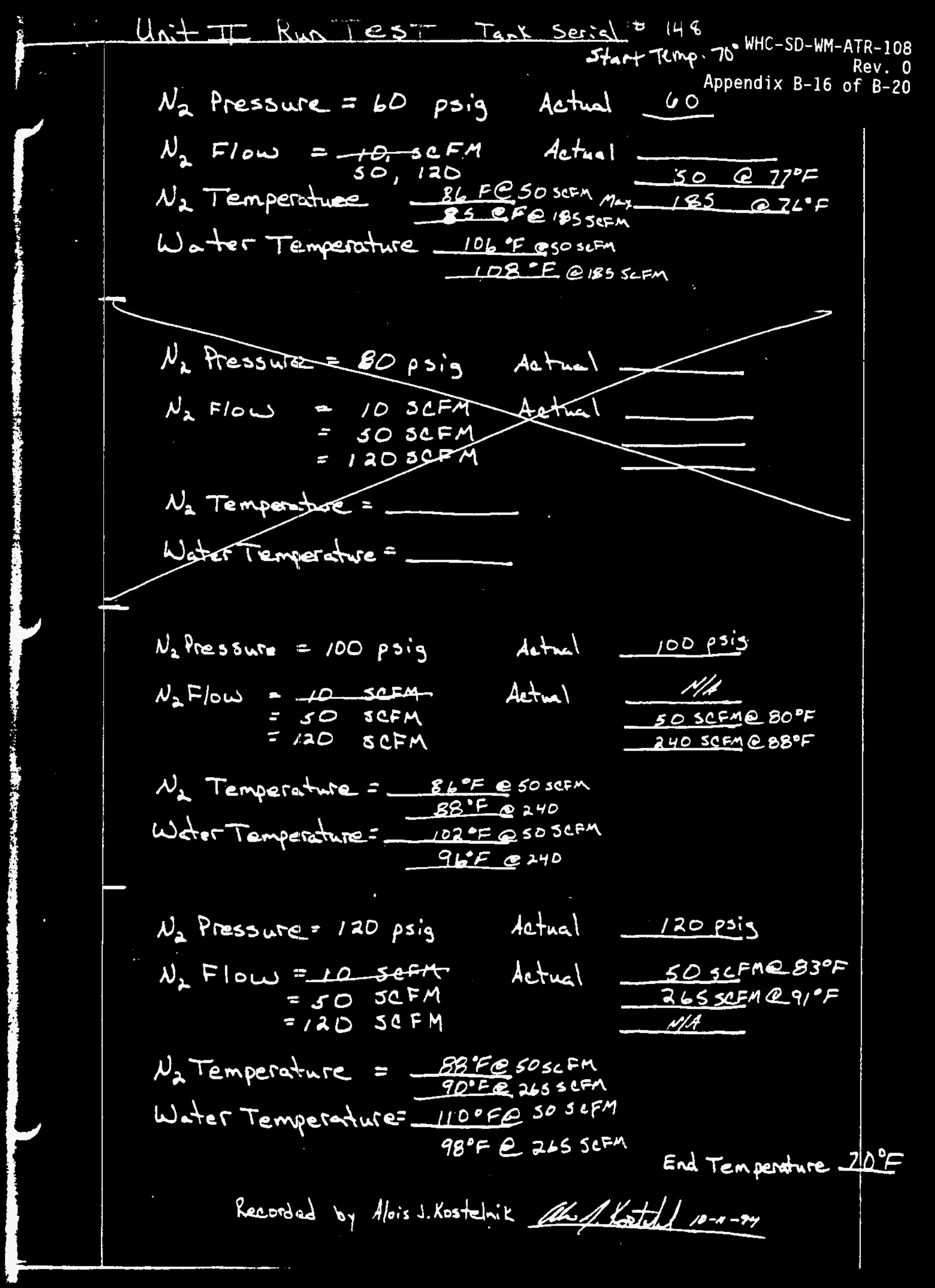




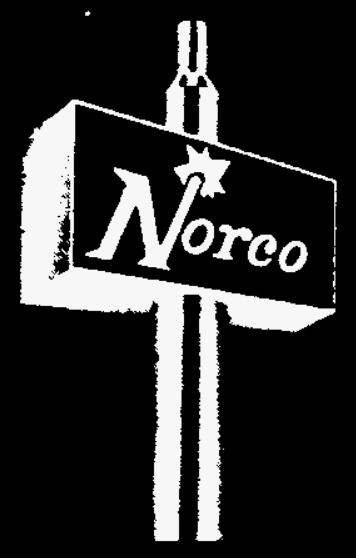

WHC-SD-WM-ATR-108

Rev. 0

Appendix B-17 of B-20

\section{WELDING, SAFETY, MEDICAL GASES AND SUPPLIES}

1121 West Amity Road , Boise, Idaho 83705

(208) 336-1643, FAX (208) 384-1720

Reference: WHC-SD-WM-ATP-108

Norco Revise Exception Lists

TANK

HLD-1530-SS-250

\#148
VAPORIZER

FCWBLX6X21/Propane

\# X940421-1
TRAILER

Trail Max

\#T69FS2726RA065102

STEP \#

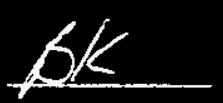

4.2 .3

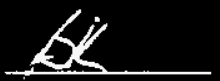

4.6 .3

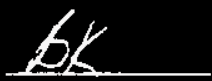

4.3 .5

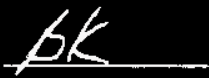

4.6.8

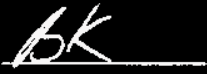

4.11

4.15 .18

4.14

4.15 .4

bK

bK

bk

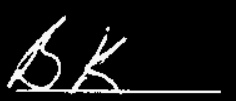

ASME Stamp Supplied

$\mathrm{N}_{2}$ Outlet Pressure Indicator Installed

Fill Hose Connected

$\mathrm{N}_{2}$ Safety Relief Mounted

Additional Support Added to Propane Vent Line

DOT Placards Installed on Propane Tank

Labeling complete as per Appendix B page $9 \& 10$

Documentation Complete / See Attached

4.13 All Suspect Fasteners We Charged According to Spec.

3.5 Documentation Complete / See Attached

3.6 Documentation Complete / See Attached

23" channel Are Spannnedon Cross Member and Welded to support N2 Skid and Vaporizers.
Bradley M K.ttridge

IDAHO

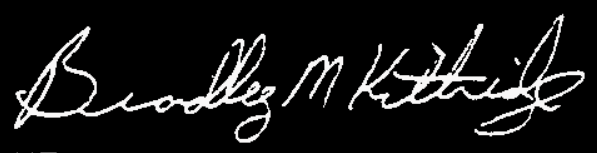


Norco

1121 West Amity Road

Boise, Idaho, 83705

\section{Attn: Brad Rittridge}

Re: CEXI Job No 940421 - Norco P.O. 28765

Brad;

This letter is to confirm that the total propane flow with the unit vaporizing 25,000 scfh of nitrogen and $325 \mathrm{scfh}$ of propane will be 197 cubic feet of propane per hour. That equates to 5.78 gallons per hour of propane. For the unit to operate at full flow for 16 hours, the fuel tank would have to be approximately 95 gallons.

The consumption is as follows

$$
\begin{aligned}
& \text { Nitrogen vaporization - 25,000 scfh - } \\
& \text { Propane flow } \quad 167.5 \mathrm{cfh} \\
& \text { Generator Set } 4.3 \text { Kilowatts continuous } \\
& \text { Propane flow } \\
& 27.7 \mathrm{cfh} \\
& \text { Propane Vaporization Requirement - } \\
& 1.59 \mathrm{cfh} \\
& \text { Total Flow } \\
& 196.79 \mathrm{cfh}
\end{aligned}
$$

The power requirements for the system are as flows.

Controls Including Water Heaters Water Pump

Total Power Required
3 amps, 120 vac 15.8 amps at $120 \mathrm{vac}$ 7.9 amps at 240 vac 18.3 amps at full load

The generator set is capable of 35 amps at 120 vac full load continuous power generation. The question that Westinghouse raised may be based on the receptacle rating. At any rate we will be supplying a new nameplate to reflect the correct amperage rating.

On a more positive note, for you at least. It turns out that our purchasing department made $\mathbf{a}$ error and ordered water heaters that are double the reguired size. The units should have been the Model 255. Instead the model ordered was a 405 . That means that for the most part, one of the units will be in the stand by mode almost all the time. The fuel consumption on the units will not be any higher because of this, you just have more water heating capacity than you will ever need. The only time the second water heater should come 
on is during times of extremely cold $\left(-20^{\circ} \mathrm{F}\right)$ anblent temperatures. During cold ambient temperatures, the second water heater should only come on for very short periods of time.

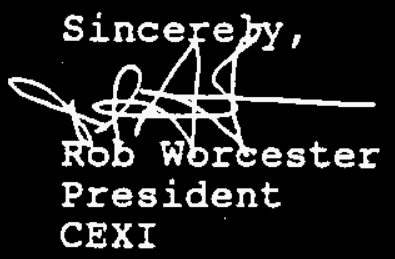


OST-IB-9A TLE TEZ TI MORLO KENNEW

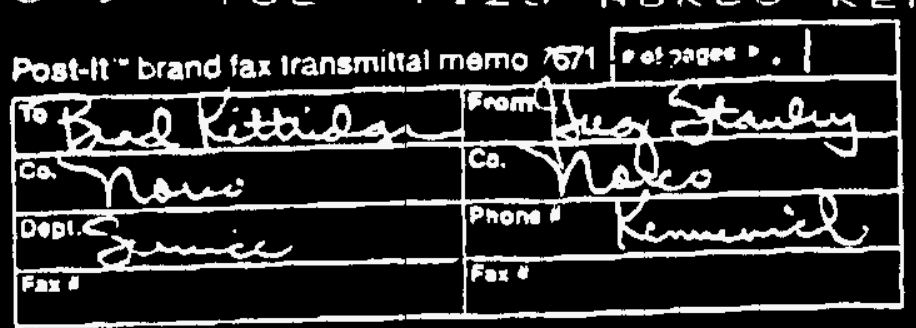

WHC-SD-WM-ATR-108 Rev. 0

Appendix B-20 of B-20

\section{Ferivisater}

PERFORMER II 3/8 IN. (9.5MM) I.D. 2BR 300 P.S.I. W.P.

TUBE

PANTORCAMENT

COVत्र:

COLOR

TEMRERATURZ RANCE

TYPE OF BRANDINE
Blended Nitrile.

i or 2 Textile Braids.

Neoprene.

Red.

$-40^{\circ} \mathrm{F}$ to $+180^{\circ} \mathrm{F}$

Ink Print.
WORKING PR25SURE TIPE OF COUPLAY
225.300 PSt.

Barbed Insents, Quick Acling, or Long Shank. Clamps-Interlocking. Single Boil, Band, or Wire.

\section{Fectures}

- Neoprene cuver

- Blended nitrile tube

- Continuous permanent brano

- Wide range of sizes

- Braid reiniorcement
Benefits

- Abrasion. oll, and weather resistant

- Madium oil resistance

- Easy identification

- For many applications

- Better coupling relention for impulse apiplications

(1)

\section{Morkets}

Assembly/Manutacturers

Construction Industry

Forest Industry

Metal Working

Mining

Ship Building

Plastic Molding

\section{Applications}

Pneumatic tods on production line. Provide powar to air operated equipment. - Convey air and water. 


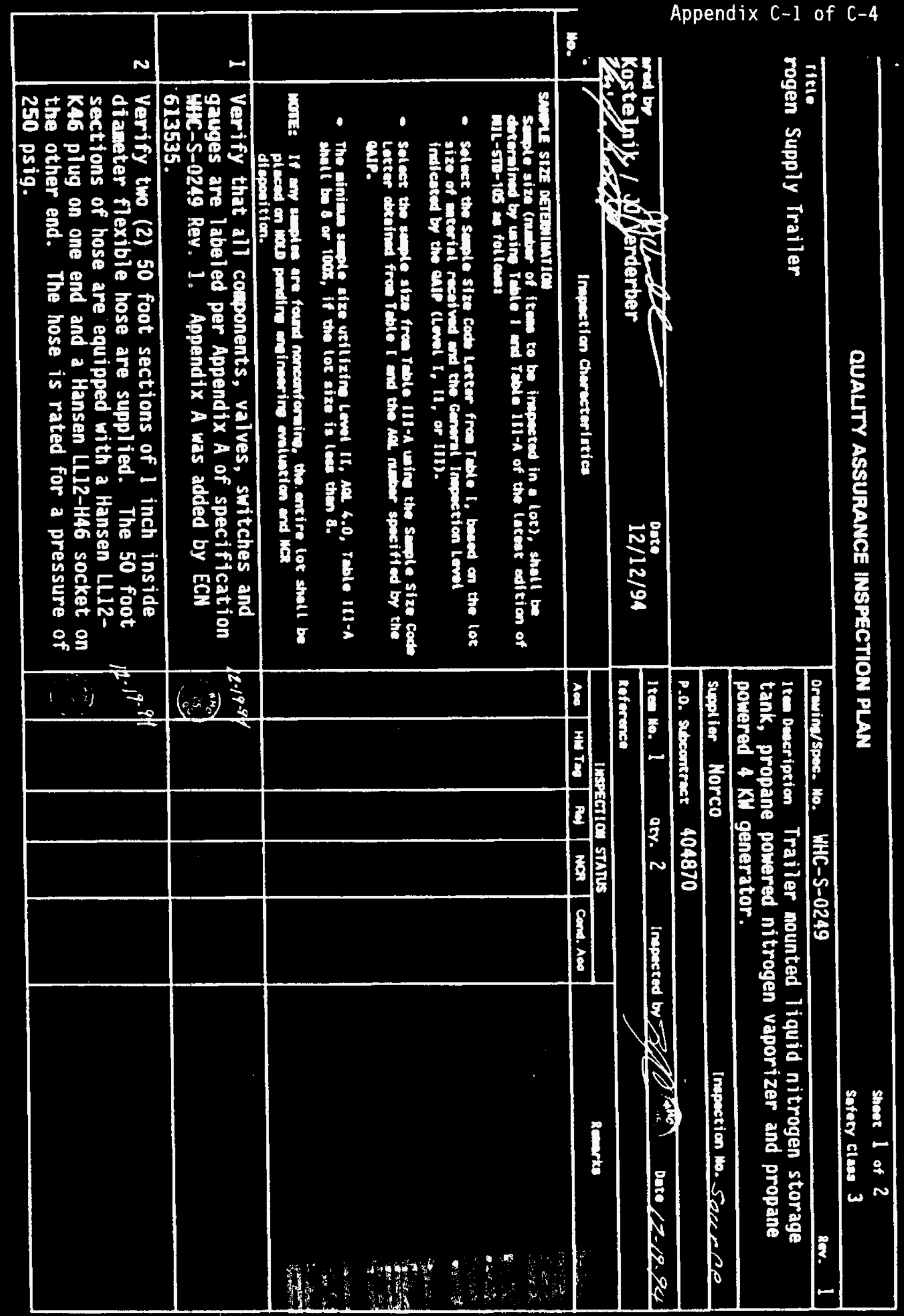




\begin{tabular}{|c|c|c|c|c|c|c|c|}
\hline & & & & & & & \\
\hline & & & & & & & \\
\hline & & & & & & & \\
\hline & & & & & & & \\
\hline & & & & & & & \\
\hline & & & & & & & \\
\hline & & & & & & & \\
\hline & & & & & & & \\
\hline & & & & & 6 & 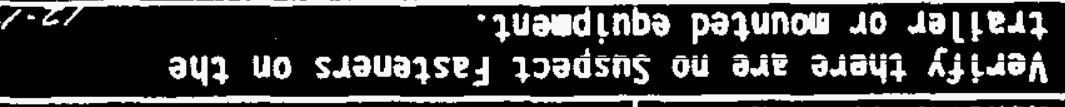 & 9 \\
\hline & & & & & $\dot{b}^{1}$ & 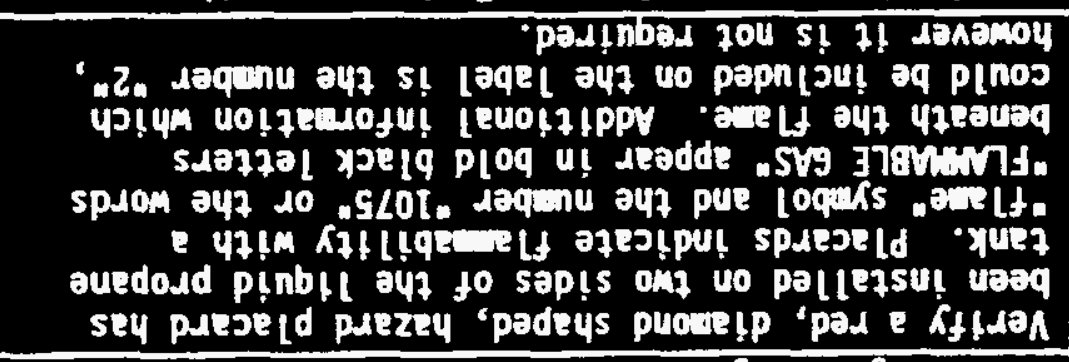 & 5 \\
\hline & & & & & $\left(e_{0}^{10}\right.$ & 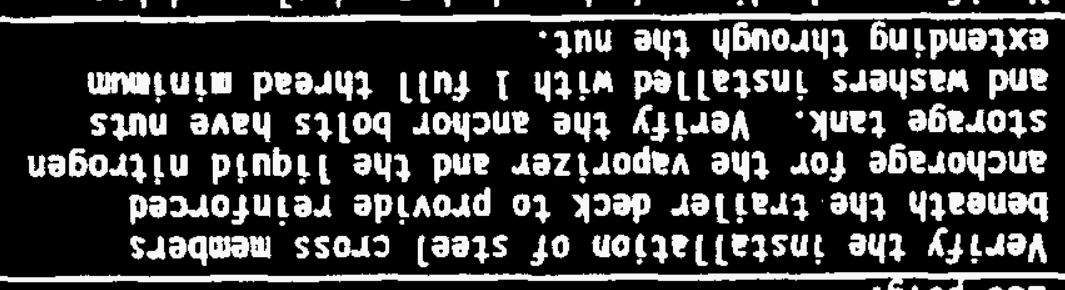 & $t$ \\
\hline & & & & & 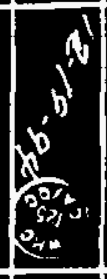 & 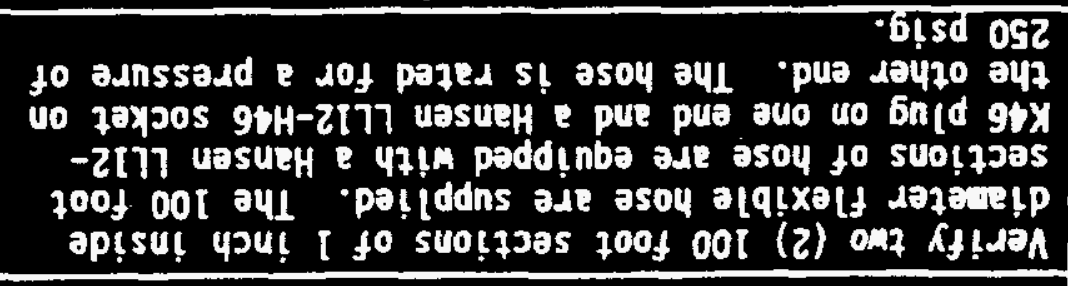 & $\varepsilon$ \\
\hline 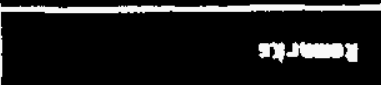 & sov woos & $\frac{y+1}{3175}$ & Th & कo & sov & 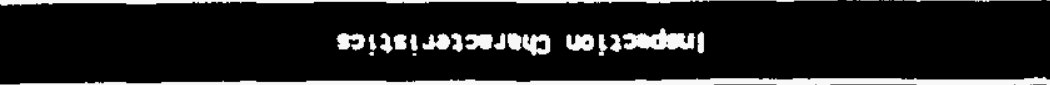 & 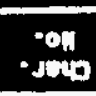 \\
\hline
\end{tabular}

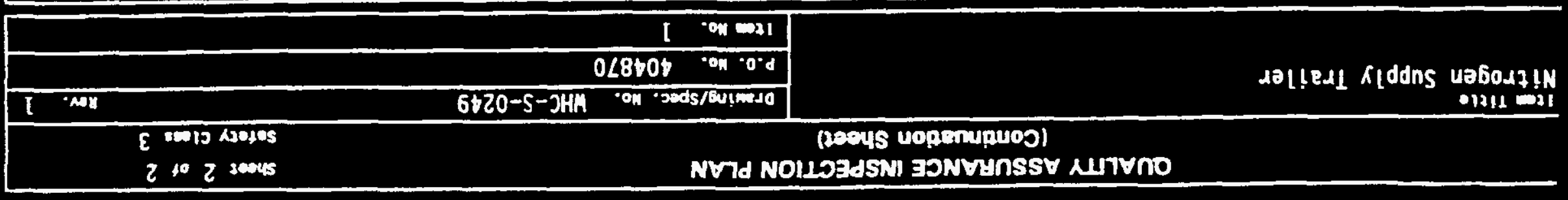




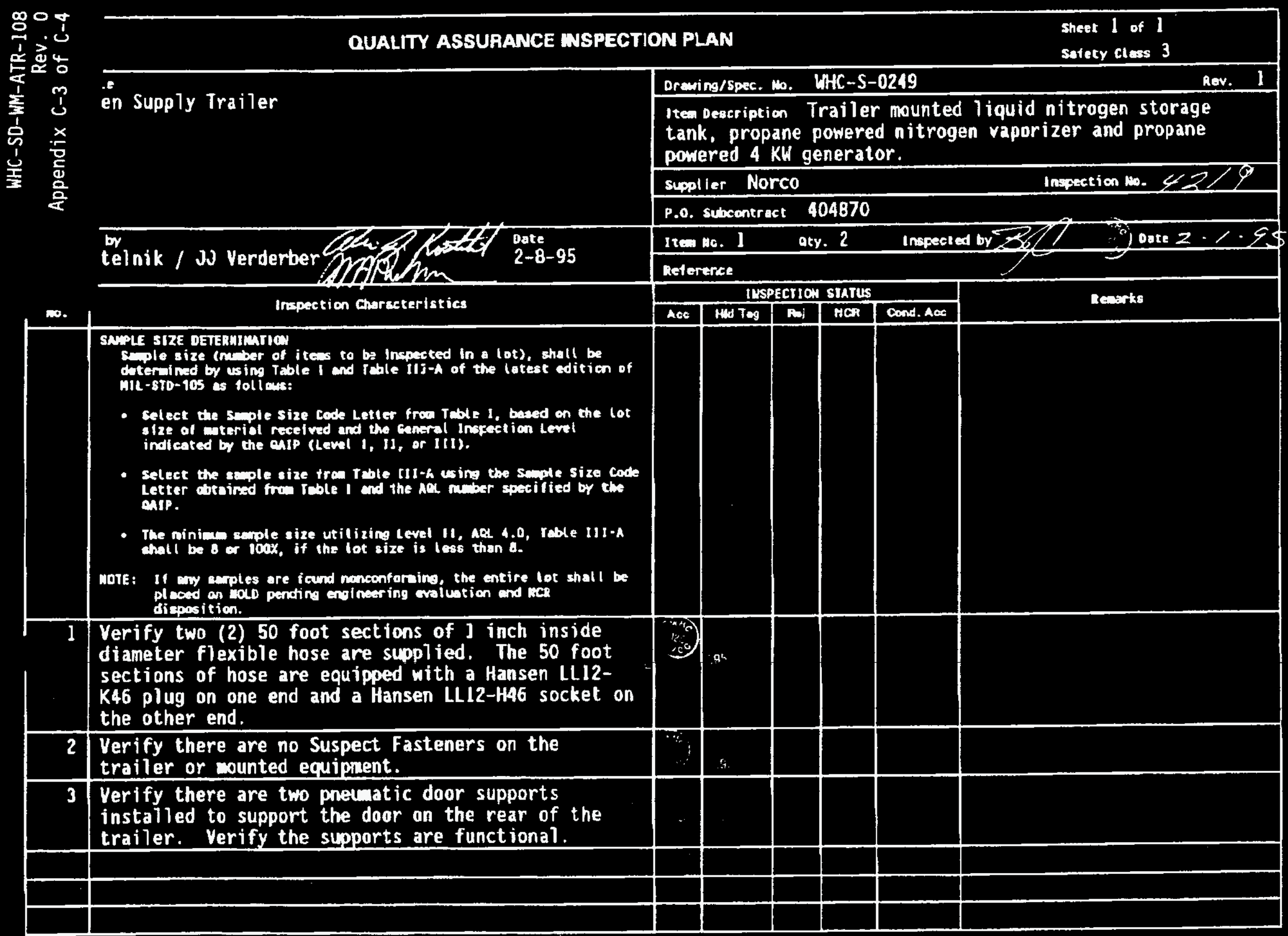




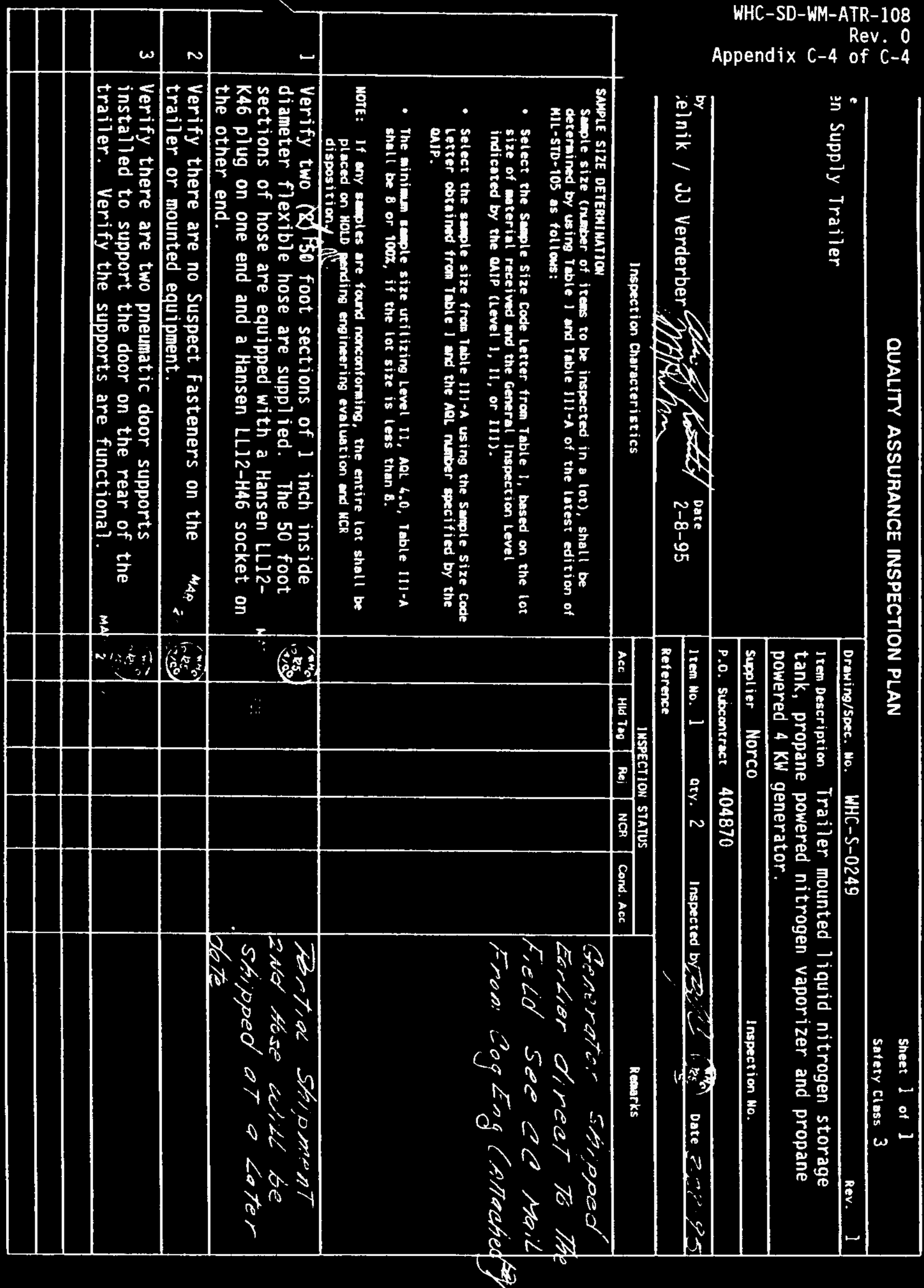

